\title{
Sedimentary phosphorus and iron cycling in and below the oxygen minimum zone of the northern Arabian Sea
}

\author{
P. Kraal ${ }^{1, *}$, C. P. Slomp ${ }^{1}$, D. C. Reed ${ }^{1}$, G.-J. Reichart ${ }^{1,2}$, and S. W. Poulton ${ }^{3}$ \\ ${ }^{1}$ Department of Earth Sciences-Geochemistry, Faculty of Geosciences, Utrecht University, Budapestlaan 4, P.O. Box 80.021, \\ 3508 TA Utrecht, The Netherlands \\ ${ }^{2}$ Marine Biogeosciences, Alfred Wegener Institute for Polar and Marine Research, Am Handelshafen 12, \\ 27570 Bremerhaven, Germany \\ ${ }^{3}$ School of Civil Engineering and Geosciences, Newcastle University, Drummond Building, \\ Newcastle upon Tyne NE1 7RU, UK \\ * now at: Southern Cross GeoScience, Southern Cross University, P.O. Box 157, Lismore, 2480 New South Wales, Australia
}

Correspondence to: P. Kraal (peter.kraal@scu.edu.au)

Received: 23 December 2011 - Published in Biogeosciences Discuss.: 26 March 2012

Revised: 29 May 2012 - Accepted: 18 June 2012 - Published: 16 July 2012

\begin{abstract}
In this study, we investigate phosphorus (P) and iron $(\mathrm{Fe})$ cycling in sediments along a depth transect from within to well below the oxygen minimum zone (OMZ) in the northern Arabian Sea (Murray Ridge). Pore-water and solid-phase analyses show that authigenic formation of calcium phosphate minerals $(\mathrm{Ca}-\mathrm{P})$ is largely restricted to where the OMZ intersects the seafloor topography, likely due to higher depositional fluxes of reactive $\mathrm{P}$. Nonetheless, increased ratios of organic carbon to organic $\mathrm{P}\left(\mathrm{C}_{\text {org }} / \mathrm{P}_{\text {org }}\right)$ and to total reactive $\mathrm{P}\left(\mathrm{C}_{\text {org }} / \mathrm{P}_{\text {reactive }}\right)$ in surface sediments indicate that the overall burial efficiency of $\mathrm{P}$ relative to $\mathrm{C}_{\text {org }}$ decreases under the low bottom water oxygen concentrations (BWO) in the OMZ. The relatively constant Fe/Al ratio in surface sediments along the depth transect suggest that corresponding changes in Fe burial are limited. Sedimentary pyrite contents are low throughout the $\sim 25 \mathrm{~cm}$ sediment cores at most stations, as commonly observed in the Arabian Sea OMZ. However, pyrite is an important sink for reactive $\mathrm{Fe}$ at one station in the OMZ. A reactive transport model (RTM) was applied to quantitatively investigate $\mathrm{P}$ and $\mathrm{Fe}$ diagenesis at an intermediate station at the lower boundary of the OMZ (bottom water $\mathrm{O}_{2}: \sim 14 \mu \mathrm{mol} \mathrm{L}^{-1}$ ). The RTM results contrast with earlier findings in showing that Fe redox cycling can control authigenic apatite formation and $\mathrm{P}$ burial in Arabian Sea sediment. In addition, results suggest that a large fraction of the sedimentary Ca-P is not authigenic, but is instead deposited from the water column and buried. Dust
\end{abstract}

is likely a major source of this Ca-P. Inclusion of the unreactive $\mathrm{Ca}-\mathrm{P}$ pool in the $\mathrm{C}_{\text {org }} / \mathrm{P}$ ratio leads to an overestimation of the burial efficiency of reactive $\mathrm{P}$ relative to $\mathrm{C}_{\mathrm{org}}$ along the depth transect. Moreover, the unreactive Ca-P accounts for $\sim 85 \%$ of total Ca-P burial. In general, our results reveal large differences in $\mathrm{P}$ and $\mathrm{Fe}$ chemistry between stations in the $\mathrm{OMZ}$, indicating dynamic sedimentary conditions under these oxygen-depleted waters.

\section{Introduction}

Iron $(\mathrm{Fe})$ and phosphorus $(\mathrm{P})$ are essential nutrients in the world's oceans, controlling primary productivity in a variety of marine settings on both short and long timescales (Tyrrell, 1999; Arrigo, 2005). Burial in the sediment is the main pathway by which $\mathrm{Fe}$ and $\mathrm{P}$ are ultimately removed from the water column. In oxic surface sediments, the geochemical dynamics of Fe and P are strongly connected as iron (oxyhydr)oxides scavenge dissolved phosphate produced during organic matter (OM) degradation. This limits the diffusive P flux from the sediment to the water column. Upon burial below the oxic zone, reductive dissolution of these $\mathrm{Fe}$ (oxyhydr)oxides and release of the associated phosphate to the pore-water facilitates the precipitation of Ca phosphate minerals (authigenic Ca-P), mainly as carbonate fluorapatite (Froelich et al., 1988; Van Cappellen and Berner, 1988; 


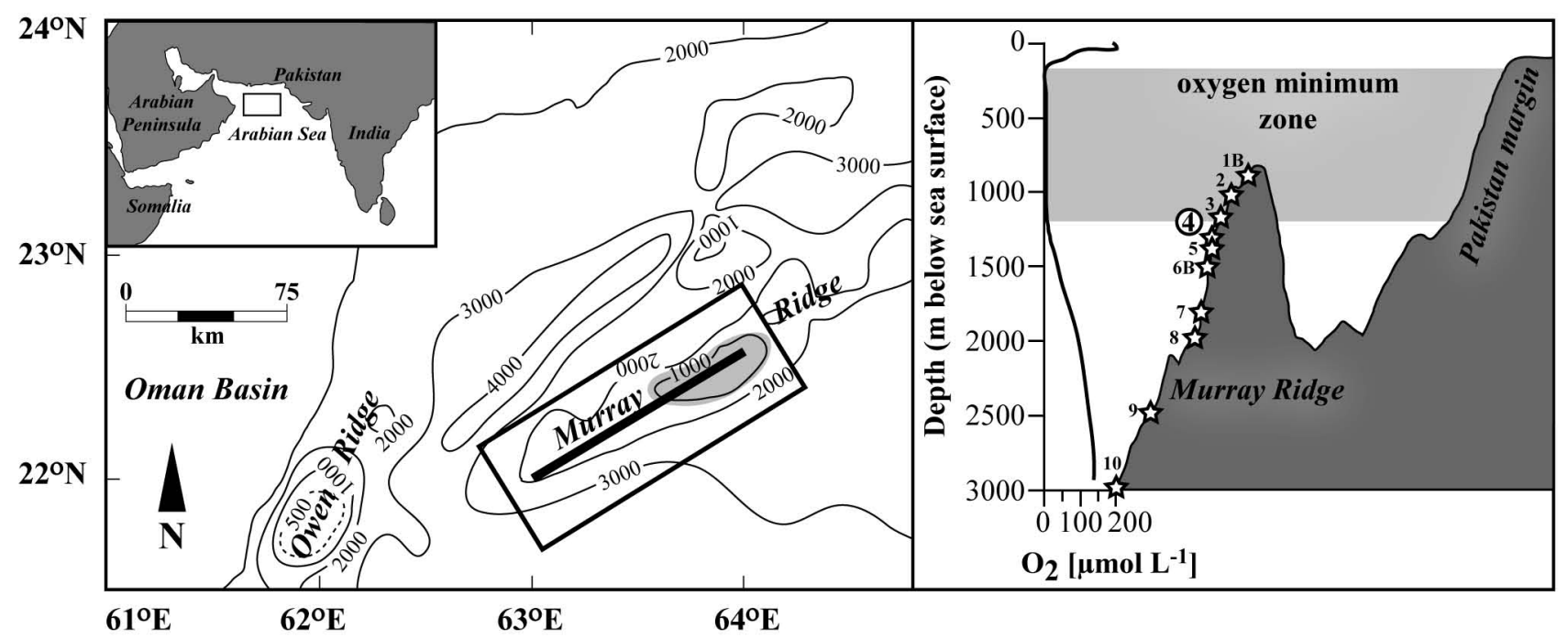

Fig. 1. Left panel: bathymetric map of the Arabian Sea with the location of the Murray Ridge study area indicated with a rectangle. The thick black line in the rectangle specifies the depth transect along which sampling was done in this study. Inset shows general regional geography. Right panel: schematic representation of the Murray Ridge and water column dissolved $\mathrm{O}_{2}$ profile, with stations indicated with star symbols and station number. Station 4, located in the lower boundary of the OMZ, was used for the reactive transport modelling part of this study (see Sects. 3 and 5) and is highlighted.

Slomp et al., 1996a). This process of sink switching transforms $\mathrm{P}$ in labile reactive phases such as $\mathrm{OM}$ and $\mathrm{Fe}$ (oxyhydr)oxides into stable authigenic $\mathrm{Ca}-\mathrm{P}$, which constitutes the principal long-term sedimentary sink of non-detrital $\mathrm{P}$ (Ruttenberg and Berner, 1993; Anderson et al., 2001). At the same time, the pore-water $\mathrm{Fe}^{2+}$ produced by reductive dissolution of Fe (oxyhydr)oxides may react with reduced sulfur (S) species in the pore-water to form iron sulfide minerals, with stable $\mathrm{FeS}_{2}$ being the main long-term sink of reactive $\mathrm{Fe}$ in marine sediments deposited beneath an oxic water column (Raiswell and Canfield, 1998).

Phosphorus is delivered from the water column to the sea floor mainly in organic form, with secondary contributions from detrital and authigenic $\mathrm{Ca}-\mathrm{P}, \mathrm{P}$ bound to $\mathrm{Fe}$ (oxyhydr)oxides and fish debris (Suess, 1981; Froelich et al., 1988; Föllmi, 1996; Compton et al., 2000; Paytan et al., 2003). All non-detrital $P$ phases are collectively called reactive $\mathrm{P}$, which generally makes up the bulk of the $\mathrm{P}$ deposited on the seafloor (Ruttenberg and Berner, 1993; Anderson et al., 2001). Bottom water oxygen (BWO) concentrations affect the burial efficiency of reactive $\mathrm{P}$ in two ways. Firstly, $\mathrm{Fe}$ (oxyhydr)oxides are less abundant in reducing surface sediments, which decreases the capacity of the sediment to retain upward diffusing dissolved phosphate (e.g. Reed et al., 2011a, b). Secondly, the release of P from OM is enhanced relative to $\mathrm{C}$ under reducing conditions (Ingall et al., 1993; Slomp et al., 2002; Jilbert et al., 2011). Recent work by Steenbergh et al. (2011) provides a mechanistic explanation for this by showing that microbes in both oxic and anoxic organic-rich sediments are carbon-limited and use phosphatases to remove phosphate from organic matter, making the remainder of the organic matter more accessible for degradation. Because anaerobic bacteria cannot retain this phosphate (Gächter et al., 1988; Ingall and Jahnke, 1994; Hupfer et al., 2004), it is released to the pore-water. The efficiency with which $\mathrm{P}$ is buried relative to organic $\mathrm{C}$ can thus be used as an indicator of redox conditions in marine systems. The organic carbon to organic $\mathrm{P}\left(\mathrm{C}_{\mathrm{org}} / \mathrm{P}_{\text {org }}\right)$ ratio reflects the degree of redox-dependent preferential $\mathrm{P}$ regeneration from $\mathrm{OM}$, while the organic $\mathrm{C}$ to reactive $\mathrm{P}$ ratio $\left(\mathrm{C}_{\text {org }} / \mathrm{P}_{\text {reactive }}\right)$ indicates the overall $\mathrm{P}$ retention efficiency in the sediment, accounting for sink switching from OM to mineral phases (Ingall and Jahnke, 1994; Anderson et al., 2001; Algeo and Ingall, 2007; Kraal et al., 2010). The processes driving this sink-switching to mineral phases in lowoxygen settings in the open ocean are still not completely understood (Slomp and Van Cappellen, 2007; Goldhammer et al., 2010; Palastanga et al., 2011).

The northern Arabian Sea hosts a layer of intermediate waters with low oxygen concentrations $\left(<\sim 20 \mu \mathrm{mol} \mathrm{L}^{-1}\right)$ between $\sim 200$ and $1000 \mathrm{~m}$ depth. This oxygen minimum zone (OMZ, Fig. 1) is sustained by sluggish circulation of already oxygen-poor water at intermediate depths and high primary productivity, the latter driven by monsoon-induced upwelling in boreal summer (Wyrtki, 1973; Swallow, 1984; Banse, 1987; Olson et al., 1993; Lee et al., 2000). The OMZ strongly impacts marine biogeochemistry in this area. For example, extensive nitrogen loss from the water column to the atmosphere through denitrification is observed (Bange et al., 2005; Naqvi et al., 2005). In addition, burial of $\mathrm{C}_{\text {org }}$ (Kolla et 
Table 1. Site characteristics. Temperature and bottom water oxygen (BWO) concentrations are derived from CTD data. Depth unit mbss is meters below sea surface. Total organic carbon $\left(\mathrm{C}_{\mathrm{org}}\right)$ is the average in the top $2 \mathrm{~cm}(n=4)$, with standard deviation between parentheses.

\begin{tabular}{lcccccc}
\hline Station & $\begin{array}{c}\text { Latitude } \\
(\mathrm{N})\end{array}$ & $\begin{array}{c}\text { Longitude } \\
(\mathrm{E})\end{array}$ & $\begin{array}{c}\text { Depth } \\
(\mathrm{mbss})\end{array}$ & $\begin{array}{c}\text { Temperature } \\
\left({ }^{\circ} \mathrm{C}\right)\end{array}$ & $\begin{array}{c}\text { BWO } \\
\left(\mu \mathrm{mol} 1^{-1}\right)\end{array}$ & $\begin{array}{c}\mathrm{C}_{\text {org }} \\
(\text { wt } \%)\end{array}$ \\
\hline $1 \mathrm{~B}$ & $22^{\circ} 32.9^{\prime}$ & $64^{\circ} 02.4^{\prime}$ & 885 & 10.0 & 2.0 & $5.6( \pm 0.2)$ \\
2 & $22^{\circ} 33.9^{\prime}$ & $64^{\circ} 03.8^{\prime}$ & 1013 & 8.6 & 2.8 & $4.1( \pm 0.0)$ \\
3 & $22^{\circ} 19.9^{\prime}$ & $63^{\circ} 36.0^{\prime}$ & 1172 & 7.8 & 5.0 & $3.6( \pm 0.1)$ \\
4 & $22^{\circ} 18.0^{\prime}$ & $63^{\circ} 36.0^{\prime}$ & 1306 & 6.7 & 14.3 & $2.9( \pm 0.1)$ \\
5 & $22^{\circ} 09.3^{\prime}$ & $63^{\circ} 12.8^{\prime}$ & 1379 & 6.5 & 16.5 & $1.4( \pm 0.1)$ \\
$6 \mathrm{~B}$ & $22^{\circ} 04.7^{\prime}$ & $63^{\circ} 04.5^{\prime}$ & 1495 & 5.6 & 25.2 & $1.5( \pm 0.1)$ \\
7 & $22^{\circ} 18.5^{\prime}$ & $63^{\circ} 24.5^{\prime}$ & 1791 & 4.1 & 43.9 & $1.1( \pm 0.3)$ \\
8 & $22^{\circ} 08.7^{\prime}$ & $63^{\circ} 01.1^{\prime}$ & 1970 & 3.1 & 55.5 & $1.1( \pm 0.2)$ \\
9 & $22^{\circ} 06.3^{\prime}$ & $62^{\circ} 53.7^{\prime}$ & 2470 & 2.1 & 63.8 & $0.8( \pm 0.1)$ \\
10 & $21^{\circ} 55.6^{\prime}$ & $63^{\circ} 10.6^{\prime}$ & 3010 & 1.4 & 82.9 & $0.7( \pm 0.1)$ \\
\hline
\end{tabular}

Table 2. Pore-water sub sample treatment and analysis.

\begin{tabular}{llrl}
\hline Analyte & Pretreatment & Storage & Measurement \\
\hline $\mathrm{PO}_{4}^{3-}$ & $\begin{array}{l}\text { Acidified to } \mathrm{pH} \sim 1 \text { with } \\
5 \text { mol L }\end{array}$ & $4{ }^{\circ} \mathrm{C}$ & $\begin{array}{l}\text { Autoanalyzer } \\
\text { (on-board) }\end{array}$ \\
$\mathrm{NH}_{4}^{+}, \mathrm{NO}_{3}^{-}$ & - & $-20^{\circ} \mathrm{C}$ & $\begin{array}{l}\text { Autoanalyzer } \\
\text { (NIOZ lab) }\end{array}$ \\
$\mathrm{SO}_{4}^{2-}$ & - & $-20^{\circ} \mathrm{C}$ & $\mathrm{IC}^{\mathrm{a}}$ \\
$\mathrm{Fe}^{2+}$ & Acidified to $\mathrm{pH} \sim 1$ with & $4{ }^{\circ} \mathrm{C}$ & $\mathrm{ICP}^{\mathrm{b}} \mathrm{MS}$ \\
$\mathrm{F}^{-}$ & $65 \%$ suprapur $\mathrm{HNO}_{3}$ & & \\
\hline
\end{tabular}

a Ion chromatography.

$\mathrm{b}$ Induced coupled plasma-mass spectrometry.

al., 1981; Paropkari et al., 1992; Van der Weijden et al., 1999) and formation of authigenic Ca-P (Schenau et al., 2000) are enhanced in sediments where the OMZ impinges on the sea floor. The latter has been attributed to an elevated input to the sediments of labile $\mathrm{P}$ phases such as $\mathrm{OM}$ and fish debris (Schenau et al., 2000; Schenau and De Lange, 2001). Despite the high input of OM and oxygen-depleted bottom waters, there is a general lack of pyrite formation in the upper $30-40 \mathrm{~cm}$ in Arabian Sea OMZ sediments for reasons that are not fully understood (Lückge et al., 1999). Existing explanations range from low reactivity of OM or Fe (oxyhydr)oxides (Passier et al., 1997; Schenau et al., 2002) to suppression of sulfate reduction because of the abundance of Fe (oxyhydr)oxides (Law et al., 2009).

Atmospheric dust deposition is an important source of both $\mathrm{Fe}$ and $\mathrm{P}$ in the northern Arabian Sea (Badarinath et al., 2010; Okin et al., 2011). Dust input has been suggested to play an important role in the delivery of nutrient $\mathrm{Fe}$ and in regulating primary productivity in the Arabian Sea (Naqvi et al., 2010), but its role in the P cycle has so far not been investigated.

In this study, we investigate $\mathrm{P}$ and $\mathrm{Fe}$ diagenesis in sediments from the Murray Ridge area in the northern Arabian Sea. The bottom water, sediment and pore-water composition down to $\sim 25 \mathrm{~cm}$ sediment depth were analyzed at 10 stations along a water depth transect from within the OMZ to the deep sea ( $\sim 900-3000 \mathrm{~m}$ below sea surface (mbss), Fig. 1). For an intermediate station at the lower boundary of the OMZ, quantitative insight into sedimentary $\mathrm{C}_{\mathrm{org}}, \mathrm{Fe}$ and $\mathrm{P}$ dynamics is obtained by applying a reactive transport model (RTM) (Reed et al., 2011b) to the dataset.

\section{Materials and methods}

\subsection{Study area and general information}

Sampling was conducted in January 2009 during the PASOM research expedition to the Murray Ridge area in the northern Arabian Sea (Fig. 1). The Murray Ridge is a tectonic feature that rises up from the sea floor into the OMZ. Water column dissolved $\mathrm{O}_{2}$ concentrations and temperatures were measured with a conductivity, temperature, depth (CTD) profiler to which an oxygen sensor was attached (Sea-Bird SBE43, accuracy $2 \%$ (Sea-Bird Electronics Inc., 2011)). Surface sediments were collected by multi-coring at 10 stations along a depth transect from the OMZ $(885 \mathrm{~m})$ to the deep sea $(3010 \mathrm{~m})$ (Table 1). Unless indicated otherwise, sample handling and analysis were performed at the Utrecht University laboratory, The Netherlands.

\subsection{Sampling and analyses}

\subsubsection{Pore-water analyses}

Sediment cores with overlying bottom water were visually inspected to verify that the sediment-water interface was intact, after which they were capped with rubber stoppers. One core was used for immediate measurement of the dissolved oxygen penetration depth in triplicate at sub-mm resolution with a Unisense Standard OX oxygen micro-electrode (detection limit $0.3 \mu \mathrm{mol} \mathrm{L}^{-1} \mathrm{O}_{2}$ ). At the same time, a fourth core was transferred to a $\mathrm{N}_{2}$-purged glovebox. After taking 
a sample of the bottom water and siphoning off the remaining water, the sediment was sliced at $0.5-2 \mathrm{~cm}$ intervals, resolution decreasing with depth. For each sampling interval, a subsample of the wet sediment was directly transferred into a $15 \mathrm{~mL}$ glass vial that was stored in an air-tight glass jar at $-20^{\circ} \mathrm{C}$ for further geochemical analyses. The remaining sediment was transferred into $50 \mathrm{~mL}$ plastic centrifuge tubes, which were centrifuged for $20 \mathrm{~min}$ at $4500 \mathrm{rpm}$ outside the glovebox. The centrifuge tubes were then transferred back into the glovebox where the supernatant pore-water was filtered over $0.45 \mu \mathrm{m}$ Teflon filters and split into subsamples that were stored either frozen $\left(-20^{\circ} \mathrm{C}\right)$ or cooled $\left(4^{\circ} \mathrm{C}\right)$ prior to pore-water analyses (Table 2). Dissolved phosphate concentrations were measured on board (QuAAtro autoanalyzer, Seal Analytical) within $16 \mathrm{~h}$ of pore-water sampling. Dissolved nitrate and ammonium concentrations were measured with an autoanalyser at the Royal Netherlands Institute for Sea Research (NIOZ) in Den Burg, The Netherlands. Dissolved fluoride concentrations were measured in subsamples of the remaining bulk pore-water using the colorimetric method of Greenhalgh and Riley (1961). Dissolved Fe concentrations were measured with an inductively coupled plasma mass spectrometer (ICP-MS, ThermoFisher Scientific Element2-XR). Replicate analyses indicated that the relative error for the pore-water analyses was generally $<10 \%$.

\subsubsection{Bulk solid-phase analyses}

The frozen sediment in the $15 \mathrm{~mL}$ glass vials was freezedried and then ground with an agate mortar and pestle in an Ar-purged glovebox. Total solid-phase $\mathrm{Ca}, \mathrm{Fe}, \mathrm{Mn}, \mathrm{P}$ and $\mathrm{S}$ concentrations were determined after digestion of a $0.125 \mathrm{~g}$ sediment subsample in a mixture of concentrated $\mathrm{HF}, \mathrm{HNO}_{3}$ and $\mathrm{HClO}_{4}$ at $90^{\circ} \mathrm{C}$ and final dissolution in $1 \mathrm{~mol} \mathrm{~L}^{-1} \mathrm{HCl}$, followed by analysis using an inductively coupled plasma optical emission spectrometer (ICP-OES; Perkin Elmer Optima 3000). Accuracy and precision of the measurements were established by measuring laboratory reference materials and sample replicates; relative errors were $<5 \%$ for all reported elements. Total $\mathrm{Ca}$ was used to calculate the $\mathrm{CaCO}_{3}$ content of the samples after correction for clay-associated $\mathrm{Ca}$ : $\mathrm{CaCO}_{3}=2.5 \times($ total $\mathrm{Ca}-0.345 \times$ total $\mathrm{Al})$, where 2.5 is the weight fraction of $\mathrm{Ca}$ in $\mathrm{CaCO}_{3}$ and 0.345 is the typical $\mathrm{Ca} / \mathrm{Al}$ weight ratio in clay (Turekian and Wedepohl, 1961; Reichart et al., 1997). For $\mathrm{C}_{\text {org }}$ analysis, a $0.2 \mathrm{~g}$ sediment subsample was decalcified by reacting twice with $1 \mathrm{~mol} \mathrm{~L}^{-1}$ $\mathrm{HCl}(4 \mathrm{~h}$ and $12 \mathrm{~h})$. After two subsequent rinses with ultrapure water, the decalcified samples were freeze-dried and organic $\mathrm{C}$ and $\mathrm{N}$ were measured with a CNS analyzer (Fisons Instruments NA 1500). Earlier tests have shown that the amount of $\mathrm{C}_{\text {org }}$ hydrolyzed by the $\mathrm{HCl}$ treatment is negligible (Van Santvoort et al., 2002). The relative error in $C_{\text {org }}$ analysis was less than $1 \%$ based on repeated measurements of reference materials. The $15 \mathrm{~mL}$ glass vials with the re- maining dried and ground sediment were stored in air-tight jars prior to further analyses.

\subsubsection{Sequential $F e$ and $P$ extraction}

Sediments from stations $1 \mathrm{~B}, 2,3,4,6 \mathrm{~B}, 8$ and 10 were analyzed for solid-phase $\mathrm{Fe}$ and $\mathrm{P}$ speciation. One subsample $(\sim 50 \mathrm{mg})$ was used for Fe fractionation with the sequential extraction procedure developed by Poulton and Canfield (2005). The procedure extracts four $\mathrm{Fe}$ fractions: (1) carbonate-associated $\mathrm{Fe}\left(\mathrm{Fe}_{\text {carb }}\right)$, extracted for $24 \mathrm{~h}$ with $1 \mathrm{~mol} \mathrm{~L}^{-1}$ sodium acetate brought to $\mathrm{pH} 4.5$ with acetic acid; (2) $\mathrm{Fe}$ in amorphous oxides $\left(\mathrm{Fe}_{\mathrm{ox} 1}\right.$, e.g. ferrihydrite), extracted for $48 \mathrm{~h}$ with $1 \mathrm{~mol} \mathrm{~L}^{-1}$ hydroxylamine- $\mathrm{HCl}$ in $25 \%$ v:v acetic acid; (3) $\mathrm{Fe}$ in crystalline oxides $\left(\mathrm{Fe}_{\mathrm{ox} 2}\right.$, e.g. goethite, akaganéite and hematite), extracted for $2 \mathrm{~h}$ with a solution of $50 \mathrm{~g} \mathrm{~L}^{-1}$ sodium dithionite buffered to $\mathrm{pH}$ 4.8 with $0.35 \mathrm{~mol} \mathrm{~L}^{-1}$ acetic acid $/ 0.2 \mathrm{~mol} \mathrm{~L}^{-1}$ sodium citrate; and (4) $\mathrm{Fe}$ in recalcitrant oxides (mostly magnetite) $\left(\mathrm{Fe}_{\mathrm{mag}}\right)$, extracted for $6 \mathrm{~h}$ with $0.2 \mathrm{~mol} \mathrm{~L}^{-1}$ ammonium oxalate $/ 0.17 \mathrm{~mol} \mathrm{~L}^{-1}$ oxalic acid. All Fe extractions were performed at room temperature.

A second subsample (1-2 g) was used to determine acid volatile sulfur (AVS) and chromium-reducible sulfur (CRS). Acid volatile sulfur was liberated by adding $6 \mathrm{~mol} \mathrm{~L}^{-1} \mathrm{HCl}$ to the sample. The $\mathrm{H}_{2} \mathrm{~S}$ that formed was purged and trapped in a $1 \mathrm{~mol} \mathrm{~L}^{-1} \mathrm{AgNO}_{3}$ solution. Chromium-reducible sulfur was determined using the chromous chloride distillation method (Canfield et al., 1986). Boiling with $2 \mathrm{~mol} \mathrm{~L}^{-1}$ chromous chloride in $10 \% \mathrm{HCl}$ reduced pyrite-sulfur to $\mathrm{H}_{2} \mathrm{~S}$, which was trapped in a $1 \mathrm{molL}^{-1} \mathrm{AgNO}_{3}$ solution. Precipitates from the AVS and pyrite distillation procedures were separately filtered and dried, after which the AVS and CRS concentrations for each sample were calculated from the $\mathrm{Ag}_{2} \mathrm{~S}$ dry weights on the filters. The relative errors for CRS measurements were generally around $10 \%$. The concentrations of $\mathrm{Fe}$ in sulfide minerals were calculated with the assumption that AVS represents iron monosulfides ( $\mathrm{FeS}$; $\left.\mathrm{Fe}_{\mathrm{AVS}}\right)$, and CRS represents pyrite $\left(\mathrm{FeS}_{2} ; \mathrm{Fe}_{\text {pyrite }}\right)$. Iron in the extracts was measured with ICP-OES (stations 1B, 4, 6B and 8) or atomic absorption (stations 2, 3 and 10). Total errors were generally $<5 \%$ based on replicate measurements. Highly reactive $\mathrm{Fe}\left(\mathrm{Fe}_{\mathrm{HR}}\right)$ was calculated as the sum of all the above-mentioned Fe fractions: $\mathrm{Fe}_{\text {carb }}+\mathrm{Fe}_{\mathrm{ox} 1}+\mathrm{Fe}_{\mathrm{ox} 2}+$ $\mathrm{Fe}_{\text {mag }}+\mathrm{Fe}_{\mathrm{AVS}}+\mathrm{Fe}_{\text {pyrite }}$ (Poulton and Canfield, 2005). Iron and sulfur analyses for stations 2, 3 and 10 were performed at the School of Civil Engineering and Geosciences at Newcastle University, United Kingdom.

A third subsample $(100 \mathrm{mg}$ ) was subjected to the SEDEX sequential $\mathrm{P}$ extraction procedure developed by Ruttenberg (1992) as modified by Slomp et al. (1996a), but including the exchangeable $\mathrm{P}$ step. The SEDEX procedure separates total sediment $\mathrm{P}$ into (1) exchangeable $\mathrm{P}$ and $\mathrm{P}$ associated with: (2) easily reducible iron (oxyhydr)oxides (Febound $\mathrm{P} ; \mathrm{P}_{\mathrm{Fe}}$ ); (3) $\mathrm{CaCO}_{3}$, authigenic and biogenic calcium 
Table 3. Chemical species included in the model, after Reed et al. (2011b).

\begin{tabular}{|c|c|c|}
\hline Species & Notation & Type \\
\hline Organic carbon $^{\mathrm{a}}$ & $\mathrm{C}_{\mathrm{org}}^{\alpha, \beta, \gamma}$ & Solid \\
\hline Organic phosphorus ${ }^{\mathrm{a}}$ & $\mathrm{P}_{\text {org }}^{\alpha, \widetilde{\beta}, \gamma}$ & Solid \\
\hline Oxygen & $\mathrm{O}_{2}$ & Solute \\
\hline Nitrate & $\mathrm{NO}_{3}^{-}$ & Solute \\
\hline Manganese oxides ${ }^{\mathrm{b}}$ & $\mathrm{MnO}_{2}^{\alpha, \beta}$ & Solid \\
\hline Iron (oxyhydr)oxides ${ }^{b, c}$ & $\mathrm{Fe}(\mathrm{OH})_{3}^{\alpha, \beta}$ & Solid \\
\hline Sulfate & $\mathrm{SO}_{4}^{2-}$ & Solute \\
\hline Manganese & $\mathrm{Mn}^{2+}$ & Solute \\
\hline Iron & $\mathrm{Fe}^{2+}$ & Solute \\
\hline Ammonium/Ammonia & $\Sigma \mathrm{NH}_{4}^{+}$ & Solute \\
\hline Phosphate & $\Sigma \mathrm{H}_{2} \mathrm{PO}_{4}^{-}$ & Solute \\
\hline Hydrogen sulfide & $\Sigma \mathrm{H}_{2} \mathrm{~S}$ & Solute \\
\hline Methane & $\mathrm{CH}_{4}$ & Solute \\
\hline Elemental sulfur & $\mathrm{S}_{0}$ & Solid \\
\hline Iron monosulfide & $\mathrm{FeS}$ & Solid \\
\hline Pyrite & $\mathrm{FeS}_{2}$ & Solid \\
\hline Iron-bound phosphate & $\mathrm{Fe}-\mathrm{P}$ & Solid \\
\hline Authigenic phosphate & Auth-P & Solid \\
\hline
\end{tabular}

a There are three pools of organic species: $(\alpha)$ rapidly oxidised, $(\beta)$ slowly oxidised, and $(\gamma)$ refractory.

${ }^{b}$ There are two forms of Mn oxides and Fe (oxyhydr)oxides: $(\alpha)$ amorphous, and $(\beta)$ more crystalline.

${ }^{\mathrm{c}}$ Total $\mathrm{Fe}$ (oxyhydr)oxides represents the easily reducible $\mathrm{Fe}$ (oxyhydr)oxides as determined during sequential $\mathrm{P}$ extraction, $\mathrm{Fe}(\mathrm{OH})_{3}$ is the simplified common term for $\mathrm{Fe}$ (oxyhydr)oxides used in the model.

phosphate minerals (authigenic Ca-P; $\mathrm{P}_{\text {authi }}$ ); (4) detrital material (detrital P; $\mathrm{P}_{\mathrm{det}}$ ); and (5) organic matter (organic $\mathrm{P}$; $\mathrm{P}_{\text {org }}$ ). The extractions were performed at room temperature. The first two extraction steps (exchangeable and Fe-bound P) were completed in an Ar-purged glovebox to prevent sample oxidation that may influence $\mathrm{P}$ partitioning in reducing sediments (Kraal et al., 2009). Exchangeable $\mathrm{P}$ was determined by extraction with $1 \mathrm{~mol} \mathrm{~L}^{-1} \mathrm{MgCl}_{2}$ brought to $\mathrm{pH} 8$ with $\mathrm{NaOH}$ for $0.5 \mathrm{~h}$. An extraction with a $0.3 \mathrm{~mol} \mathrm{~L}^{-1}$ tri-sodium citrate $/ 1 \mathrm{~mol} \mathrm{~L}^{-1}$ sodium bicarbonate solution with $25 \mathrm{~g} \mathrm{~L}^{-1}$ sodium dithionite (CDB solution, $\mathrm{pH} \sim 7.6$ ) for $8 \mathrm{~h}$ and a subsequent $1 \mathrm{~mol} \mathrm{~L}^{-1} \mathrm{MgCl}_{2}$ wash step (pH 8) for $0.5 \mathrm{~h}$ followed to extract Fe-bound P. The sediment residue was then treated with a $1 \mathrm{~mol} \mathrm{~L}^{-1}$ sodium acetate solution buffered to $\mathrm{pH} 4$ with acetic acid for $6 \mathrm{~h}$ and again a $1 \mathrm{~mol} \mathrm{~L}^{-1}$ magnesium chloride wash step ( $\mathrm{pH}$ 8) for $0.5 \mathrm{~h}$ to extract authigenic Ca-P. Remaining inorganic (i.e. detrital) $\mathrm{P}$ was subsequently extracted with $1 \mathrm{~mol} \mathrm{~L}^{-1} \mathrm{HCl}(24 \mathrm{~h})$. Finally, organic $\mathrm{P}$ was obtained by combusting the sediment residue at $550^{\circ} \mathrm{C}(2 \mathrm{~h})$ followed by extraction with $1 \mathrm{~mol} \mathrm{~L}^{-1} \mathrm{HCl}(24 \mathrm{~h})$. Duplicates and internal laboratory standards were included in the extraction series. Phosphorus and Fe concentrations in the CDB extracts were measured with ICP-OES. Phosphorus concentrations in all other extracts were determined by the colorimetric method of Strickland and Parsons (1972) on a Shimadzu spectrophotometer. Errors were generally $<10 \%$. Reactive $\mathrm{P}$ was calculated as the sum of all non-detrital P-phases.

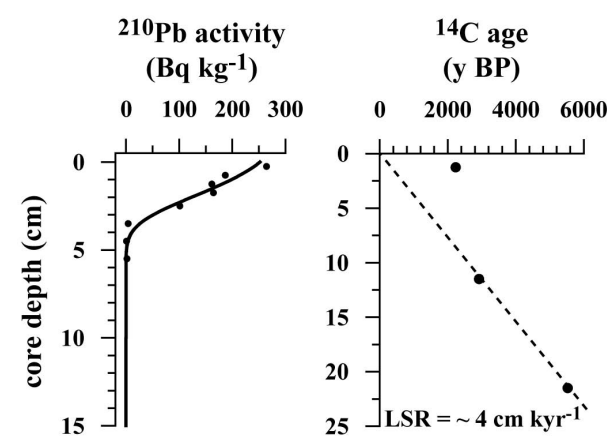

Fig. 2. Left: ${ }^{210} \mathrm{~Pb}$ profile for station 4 , after correction for supported ${ }^{210} \mathrm{~Pb}\left(66 \mathrm{~Bq} \mathrm{~kg}^{-1}\right)$ and model fit (see text for details on fitting). Points are experimental data, solid line is model fit. Right: ${ }^{14} \mathrm{C}$ ages for top, middle and bottom sample from station 4 . The linear sedimentation rate (LSR) of $\sim 4 \mathrm{~cm} \mathrm{kyr}^{-1}$ was calculated based on the age difference between the middle and bottom sample (dashed line).

\subsection{4 ${ }^{210} \mathrm{~Pb}$ and ${ }^{14} \mathrm{C}$ analyses}

Selected subsamples from the top $6 \mathrm{~cm}$ in the core from station 4 were used for ${ }^{210} \mathrm{~Pb}$ analysis (Fig. 2). The ${ }^{210} \mathrm{~Pb}$ activity in $100 \mathrm{mg}$ dry weight of sample was measured at the Royal NIOZ by $\alpha$-spectrometry of its granddaughter ${ }^{210} \mathrm{Po}$, which was precipitated on silver after digestion of the sample in an acid solution (Boer et al., 2006). ${ }^{14} \mathrm{C}$-AMS dating was performed on carbonate from hand-picked planktonic foraminiferal tests from three samples in the core from station 4 (top, middle and bottom). The ${ }^{14} \mathrm{C}$ ages were corrected using the marine reservoir age $(400 \mathrm{y})$ and calibrated using the Int09 calibration curve with the CALIB software package, version 6.0.1 (Stuiver and Reimer, 1993). The calibrated ${ }^{14} \mathrm{C}$ ages of the middle $(11.5 \mathrm{~cm}$ depth) and bottom $(21.5 \mathrm{~cm}$ depth) sample were used to calculate the linear sedimentation rate (Fig. 2).

\section{Reactive transport model}

\subsection{General description}

The sediment component of the benthic-pelagic reactive transport model (RTM) of Reed et al. (2011b) was used to investigate early diagenesis at station 4 , just below the OMZ (Fig. 1). The version used in this study describes the mass balance of 24 dissolved and particulate chemical species (Table 3) in a 1-D sediment column, where they are subject to a suite of chemical reactions and transport processes. Solutes in the model are transported by molecular diffusion, sedimentation, bioturbation and bioirrigation. Solids are transported by sedimentation and bioturbation (i.e. sediment reworking by biota). The latter is formulated as a diffusive process, biodiffusion (Goldberg and Koide, 1962; Guinasso and Schink, 1975), the intensity of which decays 
Table 4. Chemical reactions included in the model, after Reed et al. (2011b).

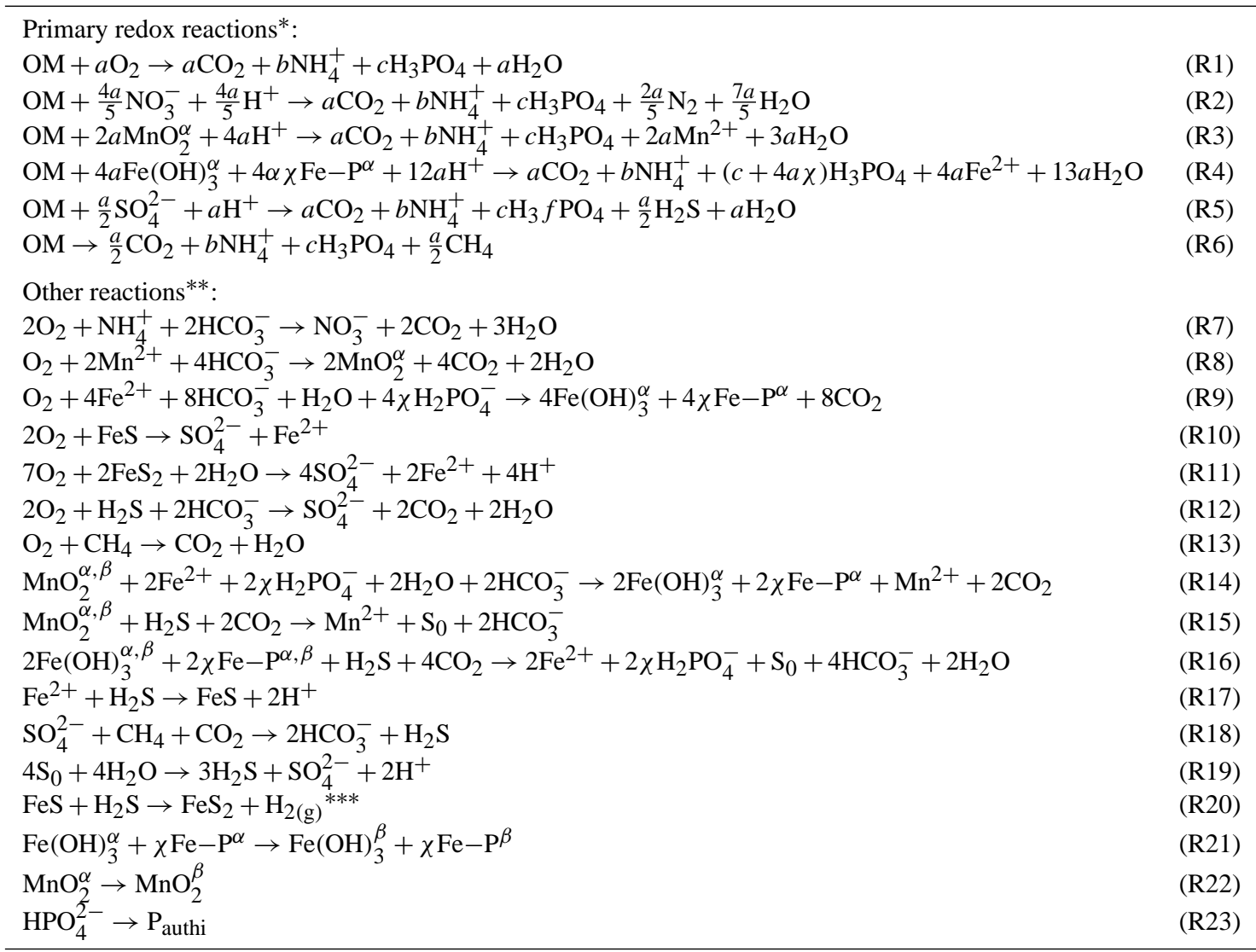

* Organic matter $(\mathrm{OM})$ is of the form $\left(\mathrm{CH}_{2} \mathrm{O}\right)_{a}\left(\mathrm{NH}_{4}^{+}\right)_{b}\left(\mathrm{H}_{3} \mathrm{PO}_{4}\right)_{c}$.

** $\chi$ represents the molar ratio between $\mathrm{P}$ and $\mathrm{Fe}$ in $\mathrm{Fe}$ (oxyhydr)oxides with adsorbed phosphate.

*** Reaction with $\mathrm{H}_{2} \mathrm{~S}$ (Reed et al., 2011a) instead of $\mathrm{S}_{0}$ (Reed et al., 2011b).

exponentially with depth to reflect a decrease of faunal intensity with sediment depth. Bioirrigation is modelled as a non-local exchange process (Boudreau, 1984; Emerson et al., 1984). Compaction following sediment burial is represented as an exponential decrease in porosity with sediment depth.

The model contains two groups of reactions: primary redox reactions and other reactions (Table 4). The primary redox reactions describe the degradation of OM by a succession of oxidants following a Monod scheme (Boudreau, 1997), in which the oxidant with the highest energy yield $\left(\mathrm{O}_{2}>\mathrm{NO}_{3}^{-}>\mathrm{MnO}_{2}>\mathrm{Fe}(\mathrm{OH})_{3}>\mathrm{SO}_{4}^{2-}\right)$ is used until it becomes limiting (Table 5, E1 -5). In the absence of these electron acceptors, OM degradation occurs through methanogenesis (Table 5, E6). An attenuation factor, $\Psi$, is applied to the rates of anoxic OM degradation by sulfate reduction and methanogenesis since these pathways are comparatively slow (Moodley et al., 2005). The model uses a multi-G approach (Jørgensen, 1978; Westrich and Berner, 1984) with three pools of OM that are degraded at different rates: highly reactive $(\alpha)$, less reactive $(\beta)$ and unreactive $(\gamma)$ (Table 3 ). All other reactions (Table 4, R7 - 23) are secondary and taken from Boudreau (1996), Rickard and Luther III (1997), Wang and Van Cappellen (1996) or Berg et al. (2003).

\subsection{Iron, manganese, phosphorus and sulfur dynamics}

There are two reactive pools of $\mathrm{Fe}$ (oxyhydr)oxides and $\mathrm{Mn}$ oxides in the model: amorphous $(\alpha)$ and crystalline $(\beta)$ (Table 3). In the model, $\mathrm{Fe}$ and $\mathrm{Mn}$ are deposited from the water column to the sediment surface in amorphous form. The aging of $\mathrm{Fe}$ and $\mathrm{Mn}$ minerals over time in the sediment is represented as a conversion from amorphous to crystalline form (Table 4, R21 - 22) following first-order kinetics (Table 5, E21 - 22). A fixed $\mathrm{Fe} / \mathrm{P}$ ratio for $\mathrm{Fe}$ (oxyhydr)oxides is used to account for Fe-associated $\mathrm{P}$ produced by phosphate adsorption onto and/or coprecipitation with $\mathrm{Fe}$ (oxyhydr)oxides. Iron (oxyhydr)oxides are dissolved through dissimilatory $\mathrm{Fe}$ reduction and reaction with dissolved sulfide, producing dissolved $\mathrm{Fe}^{2+}$ (Table 4, $\mathrm{R} 4$ and 16). Reactions between dissolved $\mathrm{Fe}^{2+}$ and $\mathrm{H}_{2} \mathrm{~S}$ drive the formation of $\mathrm{Fe}$ monosulfides and pyrite (Table 4, R17 and 20). Reaction with dissolved oxygen causes the oxidation of $\mathrm{Fe}^{2+}$ and precipitation of Fe (oxyhydr)oxides (Table 4, R9) and the oxidation of 
Table 5. Primary and secondary redox reaction equations after Reed et al. (2011b). Superscript and subscript $i$ denote the type of organic matter $(\alpha, \beta, \gamma$ : see text for details).

\begin{tabular}{|c|c|}
\hline$R_{\mathrm{O}_{2}}^{i}=k_{i} C_{\mathrm{org}}^{i}\left(\frac{\left[\mathrm{O}_{2}\right]}{k_{\mathrm{O}_{2}}+\left[\mathrm{O}_{2}\right]}\right)$ & E1 \\
\hline$R_{\mathrm{NO}_{3}^{-}}^{i}=k_{i} C_{\mathrm{org}}^{i}\left(\frac{\left[\mathrm{NO}_{3}^{-}\right]}{k_{\mathrm{NO}_{3}^{-}+\left[\mathrm{NO}_{3}^{-}\right]}}\right)\left(\frac{k_{\mathrm{O}_{2}}}{k_{\mathrm{O}_{2}}+\left[\mathrm{O}_{2}\right]}\right)$ & E2 \\
\hline$R_{\mathrm{MnO}_{2}}^{i}=k_{i} C_{\mathrm{org}}^{i}\left(\frac{\left[\mathrm{MnO}_{2}\right]}{k_{\mathrm{MnO}_{2}+\left[\mathrm{MnO}_{2}\right]}}\right)\left(\frac{k_{\mathrm{NO}_{3}^{-}}^{-}}{k_{\mathrm{NO}_{3}^{-}}+\left[\mathrm{NO}_{3}^{-}\right]}\right)\left(\frac{k_{\mathrm{O}_{2}}}{k_{\mathrm{O}_{2}}+\left[\mathrm{O}_{2}\right]}\right)$ & E3 \\
\hline$R_{\mathrm{Fe}(\mathrm{OH})_{3}}^{i}=k_{i} C_{\mathrm{org}}^{i}\left(\frac{\left[\mathrm{Fe}(\mathrm{OH})_{3}\right]}{k_{\mathrm{Fe}(\mathrm{OH})_{3}+\left[\mathrm{Fe}(\mathrm{OH})_{3}\right]}}\right)\left(\frac{k_{\mathrm{MnO}_{2}}}{k_{\mathrm{MnO}_{2}+\left[\mathrm{MnO}_{2}\right]}}\right)\left(\frac{k_{\mathrm{NO}_{3}^{-}}^{-}}{k_{\mathrm{NO}_{3}^{-}+\left[\mathrm{NO}_{3}^{-}\right]}}\right)\left(\frac{k_{\mathrm{O}_{2}}}{k_{\mathrm{O}_{2}}+\left[\mathrm{O}_{2}\right]}\right)$ & E4 \\
\hline$R_{\mathrm{SO}_{4}^{2-}}^{i}=\Psi k_{i} C_{\mathrm{Org}}^{i}\left(\frac{\left[\mathrm{SO}_{4}^{2-}\right]}{k_{\mathrm{SO}_{4}^{2-}+\left[\mathrm{SO}_{4}^{2-}\right]}}\right)\left(\frac{k_{\mathrm{Fe}(\mathrm{OH})_{3}}}{k_{\mathrm{Fe}(\mathrm{OH})_{3}}+\left[\mathrm{Fe}(\mathrm{OH})_{3}\right]}\right)\left(\frac{k_{\mathrm{MnO}_{2}}}{k_{\mathrm{MnO}_{2}+\left[\mathrm{MnO}_{2}\right]}}\right)\left(\frac{k_{\mathrm{NO}_{3}^{-}}}{k_{\mathrm{NO}_{3}^{-}}+\left[\mathrm{NO}_{3}^{-}\right]}\right)\left(\frac{k_{\mathrm{O}_{2}}}{k_{\mathrm{O}_{2}}+\left[\mathrm{O}_{2}\right]}\right)$ & E5 \\
\hline$R_{\mathrm{CH}_{4}}^{i}=\Psi k_{i} C_{\mathrm{org}}^{i}\left(\frac{k_{\mathrm{SO}_{4}^{2-}}}{k_{\mathrm{SO}_{4}^{2-}+\left[\mathrm{SO}_{4}^{2-}\right]}}\right)\left(\frac{k_{\mathrm{Fe}(\mathrm{OH})_{3}}}{k_{\mathrm{Fe}(\mathrm{OH})_{3}}+\left[\mathrm{Fe}(\mathrm{OH})_{3}\right]}\right)\left(\frac{k_{\mathrm{MnO}_{2}}}{k_{\mathrm{MnO}_{2}+\left[\mathrm{MnO}_{2}\right]}}\right)\left(\frac{k_{\mathrm{NO}_{3}^{-}}}{k_{\mathrm{NO}_{3}^{-}}+\left[\mathrm{NO}_{3}^{-}\right]}\right)\left(\frac{k_{\mathrm{O}_{2}}}{k_{\mathrm{O}_{2}}+\left[\mathrm{O}_{2}\right]}\right)$ & E6 \\
\hline$R_{1}=k_{1}\left[\mathrm{O}_{2}\right]\left[\Sigma \mathrm{NH}_{4}^{+}\right]$ & E7 \\
\hline$R_{2}=k_{2}\left[\mathrm{O}_{2}\right]\left[\mathrm{Mn}^{2+}\right]$ & E8 \\
\hline$R_{3}=k_{3}\left[\mathrm{O}_{2}\right]\left[\mathrm{Fe}^{2+}\right]$ & E9 \\
\hline$R_{4}=k_{4}\left[\mathrm{O}_{2}\right][\mathrm{FeS}]$ & E10 \\
\hline$R_{5}=k_{5}\left[\mathrm{O}_{2}\right]\left[\mathrm{FeS}_{2}\right]$ & E11 \\
\hline$R_{6}=k_{6}\left[\mathrm{O}_{2}\right]\left[\Sigma \mathrm{H}_{2} \mathrm{~S}\right]$ & E12 \\
\hline$R_{7}=k_{7}\left[\mathrm{O}_{2}\right]\left[\mathrm{CH}_{4}\right]$ & E13 \\
\hline$R_{8}=k_{8}\left[\mathrm{MnO}_{2}^{\alpha, \beta}\right]\left[\mathrm{Fe}^{2+}\right]$ & E14 \\
\hline$R_{9}=k_{9}\left[\mathrm{MnO}_{2}{ }^{\alpha, \beta}\right]\left[\Sigma \mathrm{H}_{2} \mathrm{~S}\right]$ & E15 \\
\hline$R_{10}=k_{10}\left[\mathrm{Fe}(\mathrm{OH})_{3}^{\alpha, \beta}\right]\left[\Sigma \mathrm{H}_{2} \mathrm{~S}\right]$ & E16 \\
\hline$R_{11}=k_{11}\left[\mathrm{Fe}^{2+}\right]\left[\Sigma \mathrm{H}_{2} \mathrm{~S}\right]$ & E17 \\
\hline$R_{12}=k_{12}\left[\mathrm{SO}_{4}^{2-}\right]\left[\mathrm{CH}_{4}\right]$ & E18 \\
\hline$R_{13}=k_{13}\left[\mathrm{~S}_{0}\right]$ & E19 \\
\hline$R_{14}=k_{14}[\mathrm{FeS}]\left[S_{0}\right]$ & E20 \\
\hline$R_{15}=k_{15}\left[\mathrm{Fe}(\mathrm{OH})_{3}^{\alpha}\right]$ & E21 \\
\hline$R_{16}=k_{16}\left[\mathrm{MnO}_{2}^{\alpha}\right]$ & E22 \\
\hline$R_{17}=\left\{\begin{array}{l}k_{17}\left(\left[\mathrm{HPO}_{4}^{2-}\right]-C_{\mathrm{eq}}\right),\left[\mathrm{HPO}_{4}^{2-}\right]>C_{\mathrm{eq}} \\
0,\left[\mathrm{HPO}_{4}^{2-}\right] \leq C_{\mathrm{eq}}\end{array}\right.$ & E23 \\
\hline
\end{tabular}

dissolved sulfide and Fe sulfide minerals (Table 4, R10 - 12). Manganese oxides can be reduced and dissolved by reaction with dissolved $\mathrm{Fe}^{2+}$ or sulfide (Table 4, R14-15).

Phosphorus is delivered to the sediment through deposition of Fe (oxyhydr)oxides and OM. The amount of $\mathrm{P}$ deposition is determined by the fixed Fe/ $\mathrm{P}$ ratio in Fe (oxyhydr)oxides and the $\mathrm{C} / \mathrm{P}$ ratio in the three OM pools. Phosphate release to the pore-water is governed by reductive dissolution of $\mathrm{Fe}$ (oxyhydr)oxides and degradation of the two reactive OM pools. Precipitation of phosphate in the form of Ca-P minerals (Table 4, R23) occurs when the pore-water phosphate concentration exceeds a threshold value (Table 5, E23).

An inert background concentration of $\mathrm{Fe}$ (oxyhydr)oxides, Mn oxides and S is applied throughout the sediment column to account for the presence of unreactive materials. In addition, a depositional flux of unreactive $\mathrm{Ca}-\mathrm{P}$ is included to account for the abundance of $\mathrm{Ca}-\mathrm{P}$ at the sediment surface.

\subsection{Model parameterization}

Model parameters that are changed with regard to the initial parameterization by Reed et al. (2011b) are given in Table 6 . The parameters are either constrained by the model or obtained from experimental data. A linear sedimentation rate was calculated from the ${ }^{14} \mathrm{C}$ ages of an intermediate $(11.5 \mathrm{~cm})$ and deep $(21.5 \mathrm{~cm})$ sediment sample (see Sect. 2.2.4). The depositional fluxes and degradation rates for the three $\mathrm{OM}$ pools were estimated from fitting the model to the measured $\mathrm{C}_{\text {org }}$ and $\mathrm{NH}_{4}^{+}$profiles. The total $\mathrm{C}_{\text {org }}$ flux of $\sim 25 \mu \mathrm{mol} \mathrm{cm} \mathrm{cm}^{-2} \mathrm{yr}^{-1}$ is in line with earlier data derived 
Table 6. Changed model parameters compared to Reed et al. (2011b).

\begin{tabular}{|c|c|c|c|}
\hline Parameter & Unit & Value & Source \\
\hline \multicolumn{4}{|l|}{ Boundary conditions } \\
\hline \multicolumn{4}{|l|}{ OM flux to SWI } \\
\hline- fraction $\alpha$ & $\mu \mathrm{mol} \mathrm{cm}{ }^{-2} \mathrm{yr}^{-1}$ & 18 & 1 \\
\hline- fraction $\beta$ & $\mu \mathrm{mol} \mathrm{cm}{ }^{-2} \mathrm{yr}^{-1}$ & 4.25 & 1 \\
\hline- fraction $\gamma$ & $\mu \mathrm{mol} \mathrm{cm} \mathrm{cm}^{-2} \mathrm{yr}^{-1}$ & 1.7 & 1 \\
\hline $\mathrm{MnO}_{2}$ flux to SWI & $\mu \mathrm{mol} \mathrm{cm}{ }^{-2} \mathrm{yr}^{-1}$ & 0.5 & 1 \\
\hline $\mathrm{Fe}(\mathrm{OH})_{3}$ flux to SWI & $\mu \mathrm{mol} \mathrm{cm}{ }^{-2} \mathrm{yr}^{-1}$ & 0.037 & 1 \\
\hline Authigenic Ca-P flux to SWI & $\mu \mathrm{mol} \mathrm{cm}{ }^{-2} \mathrm{yr}^{-1}$ & 0.017 & 1 \\
\hline $\mathrm{BW} \mathrm{O}_{2}$ & $\mathrm{mmol} \mathrm{L}^{-1}$ & 0.014 & 2 \\
\hline $\mathrm{BW} \mathrm{NO}--$ & $\mathrm{mmol} \mathrm{L}^{-1}$ & 0.036 & 2 \\
\hline $\mathrm{BW} \mathrm{Mn}^{2+}$ and $\mathrm{Fe}^{2+}$ & $\mathrm{mmol} \mathrm{L}^{-1}$ & 0 & 2 \\
\hline $\mathrm{BW} \mathrm{SO}_{4}^{2-}$ & $\mathrm{mmol} \mathrm{L}^{-1}$ & 29 & 2 \\
\hline $\mathrm{BW} \mathrm{NH}{ }_{4}^{+}$ & $\mathrm{mmol} \mathrm{L}^{-1}$ & 0.0026 & 2 \\
\hline $\mathrm{BW} \mathrm{HPO}_{4}^{2-}$ & $\mathrm{mmol} \mathrm{L}^{-1}$ & 0.003 & 2 \\
\hline \multicolumn{4}{|l|}{ Rate constants } \\
\hline \multicolumn{4}{|l|}{ OM decay rate } \\
\hline- fraction $\alpha$ & $\mathrm{yr}^{-1}$ & 0.25 & 1 \\
\hline- fraction $\beta$ & $\mathrm{yr}^{-1}$ & 0.0015 & 1 \\
\hline Authigenic Ca-P formation & $\mathrm{yr}^{-1}$ & 0.365 & \\
\hline $\mathrm{R}_{1}$ (nitrification) & $\mathrm{L} \mathrm{mmol}^{-1} \mathrm{yr}^{-1}$ & 500000 & 1 \\
\hline $\mathrm{R}_{10}\left(\mathrm{Fe}(\mathrm{OH})_{3}^{\beta}\right.$ reduction by $\left.\mathrm{H}_{2} \mathrm{~S}\right)$ & $\mathrm{L} \mathrm{mmol}^{-1} \mathrm{yr}^{-1}$ & 0.15 & 1 \\
\hline $\mathrm{R}_{11}$ (precipitation of $\mathrm{Fe}^{2+}$ with $\mathrm{H}_{2} \mathrm{~S}$ ) & $\mathrm{L} \mathrm{mmol}^{-1} \mathrm{yr}^{-1}$ & 0.5 & 1 \\
\hline \multicolumn{4}{|l|}{ Environmental and transport parameters } \\
\hline \multicolumn{4}{|l|}{ Porosity } \\
\hline - at surface $\left(\Phi_{0}\right)$ & $\mathrm{cm}^{3} \mathrm{~cm}^{-3}$ & 0.86 & 2 \\
\hline- at depth $\left(\Phi_{\infty}\right)$ & $\mathrm{cm}^{3} \mathrm{~cm}^{-3}$ & 0.76 & 2 \\
\hline - e-folding distance $(\lambda)$ & $\mathrm{cm}$ & 6.63 & 1 \\
\hline Sediment accumulation rate & $\mathrm{g} \mathrm{cm}^{-2} \mathrm{yr}^{-1}$ & 0.0015 & 2 \\
\hline Biodiffusion coefficient at surface $\left(\mathrm{Db}_{0}\right)$ & $\mathrm{cm}^{2} \mathrm{yr}^{-1}$ & 0.36 & 2 \\
\hline Mixing depth & $\mathrm{cm}$ & 3.5 & 2 \\
\hline Bioirrigation coefficients & $\mathrm{yr}^{-1}$ & & 1 \\
\hline$-\mathrm{O}_{2}$ & & 70 & \\
\hline$-\mathrm{SO}_{4}^{2-}, \mathrm{NH}_{4}^{+}, \mathrm{NO}_{3}^{-}, \mathrm{HPO}_{4}^{2-}, \mathrm{Mn}^{2+}, \mathrm{H}_{2} \mathrm{~S}$ & & 10 & \\
\hline$-\mathrm{Fe}^{2+}$ & & 0 & \\
\hline Maximum bioirrigation depth & $\mathrm{cm}$ & 3.5 & 2 \\
\hline $\mathrm{P}: \mathrm{Fe}$ ratio for iron-bound phosphorus & - & 0.16 & 2 \\
\hline Threshold for Ca-P precipitation $\left(C_{\mathrm{eq}}\right)$ & $\mu \mathrm{mol} \mathrm{g}^{-1}$ & 6 & 2 \\
\hline Refractory $\mathrm{MnO}_{2}$ in sediment & $\mu \mathrm{molg} \mathrm{g}^{-1}$ & 3.8 & 2 \\
\hline Refractory $\mathrm{Fe}(\mathrm{OH})_{3}$ in sediment & $\mu \mathrm{mol} \mathrm{g}-1$ & 15 & 2 \\
\hline Refractory $S$ in sediment* & $\mu \mathrm{mol} \mathrm{g}-1$ & 0 & \\
\hline Molar $\mathrm{C}: \mathrm{N}: \mathrm{P}$ ratios $\mathrm{OM}$ & - & & \\
\hline- fraction $\beta$ and $\gamma$ & & $477 / 50 / 1$ & 2 \\
\hline
\end{tabular}

from sediment traps in the Arabian Sea, which show a range of $\mathrm{C}_{\text {org }}$ settling fluxes between $\sim 15$ and $50 \mu \mathrm{mol} \mathrm{cm}^{-2} \mathrm{yr}^{-1}$ at water depths $>1000 \mathrm{~m}$ (Nair et al., 1989; Haake et al., 1993; Lee et al., 1998; Honjo et al., 1999). The input fluxes of $\mathrm{Mn}$ oxides and $\mathrm{Fe}$ (oxyhydr)oxides were constrained by the measured solid-phase and dissolved $\mathrm{Mn}$ and $\mathrm{Fe}$ pro- files, respectively. Iron (oxyhydr)oxides in the model were fitted to the profile of easily reducible $\mathrm{Fe}$ (oxyhydr)oxides as determined by extraction step 2 of the SEDEX extraction procedure (see Sect. 2.2.3). Concentrations of bottom water species (i.e. model boundary conditions) were obtained from the dataset. 
Table 7. Penetration depths of pore-water $\mathrm{O}_{2}, \mathrm{NO}_{3}^{-}$and solid-phase Mn oxides. For $\mathrm{O}_{2}$ and $\mathrm{NO}_{3}^{-}$, the penetration depth was defined as the depth at which the result was a zero reading or a stable background value around the detection limit $\left(0.05 \mu \mathrm{mol} 1^{-1}\right)$, respectively. For $\mathrm{Mn}$ oxides $\left(\mathrm{Mn}_{\mathrm{Ox}}\right)$, penetration depth was taken as the depth where total solid-phase Mn decreased to a stable background value, likely in the form of Mn carbonate.

\begin{tabular}{llll}
\hline Station & \multicolumn{3}{c}{ Penetration depth $(\mathrm{cm})$} \\
& $\mathrm{O}_{2}$ & $\mathrm{NO}_{3}^{-}$ & $\mathrm{Mn}_{\mathrm{Ox}}$ \\
\hline 1B & 0.075 & 1.25 & 0 \\
2 & 0.1 & 1.25 & 0 \\
4 & 0.25 & 3.5 & 1.25 \\
6B & 0.7 & 1.75 & 1.75 \\
10 & 1.8 & 7.5 & 8.5 \\
\hline
\end{tabular}

The average bulk C/N/P ratio for OM (477/50/1) was more or less constant $( \pm 5 \%)$ throughout the core from station 4 and this was applied to the less reactive $(\beta)$ and unreactive $(\gamma) \mathrm{OM}$ pools in the model. The high $\mathrm{C} / \mathrm{P}$ ratio for these $\mathrm{OM}$ pools is in agreement with a degraded nature of $\mathrm{OM}$ at the sediment surface in the Arabian Sea (Haake et al., 1992; Woulds and Cowie, 2009). The C/N/P ratio of highly reactive OM was set to the Redfield ratio of 106/16/1 for fresh algal material. The attenuation factor for sulfate reduction and methanogenesis was set at 0.075 (Reed et al., 2011b).

The biodiffusion coefficient at the sediment surface $\left(\mathrm{D}_{b 0}\right)$ of 0.36 was obtained by fitting a biodiffusion model, with $\mathrm{D}_{b}$ as an exponential function of depth (Boudreau, 1986), to the depth profile of unsupported ${ }^{210} \mathrm{~Pb}$ activity (Fig. 2). The unsupported ${ }^{210} \mathrm{~Pb}$ activity was calculated by subtracting the stable background ${ }^{210} \mathrm{~Pb}$ activity of $66( \pm 1.6, n=3)$ $\mathrm{Bq} \mathrm{kg}{ }^{-1}$ observed between 3.5 and $5.5 \mathrm{~cm}$ depth. Based on the stable ${ }^{210} \mathrm{~Pb}$ values from $3.5 \mathrm{~cm}$ onwards, the mixing depth (i.e. the depth to which bioturbation occurs) was set at $3.5 \mathrm{~cm}$. The rates of bioirrigation and nitrification were constrained by fitting the model to the measured $\mathrm{NH}_{4}^{+}$profile. We used a bioirrigation rate constant of 70 for $\mathrm{O}_{2}$ and 10 for other pore-water species $\left(\mathrm{SO}_{4}^{2-}, \mathrm{NH}_{4}^{+}, \mathrm{HPO}_{4}^{2-}, \mathrm{Mn}^{2+}\right.$ and $\mathrm{H}_{2} \mathrm{~S}$ ). The bioirrigation rate constants for dissolved $\mathrm{Fe}^{2+}$ and $\mathrm{NO}_{3}^{-}$were set to 0 because of its high reactivity in burrows, precluding significant penetration into the sediment (Meile et al., 2005). The depth of bioirrigation was set at $3.5 \mathrm{~cm}$, equal to the mixing depth. The bioirrigation rates were assumed to be constant with depth in the mixed sediment. The rate constants for the reactions between $\mathrm{Fe}$ (oxyhydr)oxides and $\mathrm{H}_{2} \mathrm{~S}$ (R16 in Table 4) and between $\mathrm{Fe}^{2+}$ and $\mathrm{H}_{2} \mathrm{~S}$ (R17) were constrained by fitting the profiles of $\mathrm{Fe}$ (oxyhydr)oxides, $\mathrm{Fe}^{2+}$ and $\mathrm{FeS}_{2}$.

\section{Experimental results}

\subsection{Geochemistry of surface sediments}

Figure 3 shows the trends in bulk geochemistry of surface sediments (top $2 \mathrm{~cm}$ ) along the depth transect, with OMZ boundaries as defined in Cowie and Levin (2009). Bottom water oxygen concentrations are low and relatively stable near the heart of the OMZ and increase steadily from the OMZ to the deep sea. Above the lower boundary of the OMZ, the sediments record relatively strong increases in $\mathrm{C}_{\text {org }}$ and Al-normalized $\mathrm{P}$ and $\mathrm{S}$. The $\mathrm{C}_{\text {org }} / \mathrm{P}_{\text {org }}$ and $\mathrm{C}_{\text {org }} / \mathrm{P}_{\text {reactive }}$ ratio both show an increase from the deep sea to the OMZ, suggestive of enhanced $\mathrm{P}$ regeneration from $\mathrm{OM}$ and the sediment with decreasing BWO concentrations. Manganese concentrations in the surface sediment decline with decreasing water depth and BWO concentrations, while Fe concentrations are relatively constant along the depth transect, with the exception of station 1B where the $\mathrm{Fe}$ abundance is markedly higher. Aluminum concentrations are stable in the OMZ, below which $\mathrm{Al}$ increases with increasing water depth. The trend in $\mathrm{CaCO}_{3}$ contents with water depth records a mirrorimage to that of $\mathrm{Al}$.

\subsection{Pore-water chemistry and solid-phase $\mathrm{Fe}$ and $\mathrm{P}$ fractionation}

Selected results from stations 1B, 2, 4, 6B and 10 are presented to demonstrate the changes in pore-water chemistry with water depth. The $\mathrm{NH}_{4}^{+}$and $\mathrm{HPO}_{4}^{2-}$ concentrations follow the trend in $\mathrm{C}_{\text {org }}$ contents (Fig. 3), with highest values recorded in the relatively organic-rich sediments from the OMZ (Fig. 4). The strong increase in $\mathrm{C}_{\text {org }}$ contents from station 2 to station $1 \mathrm{~B}$, which have similar BWO concentrations $\left(2.8\right.$ and $\left.2.0 \mu \mathrm{mol} \mathrm{O} \mathrm{O}_{2}^{-1}\right)$, is accompanied by a strong increase in pore-water $\mathrm{NH}_{4}^{+}$and $\mathrm{HPO}_{4}^{2-}$. The subsurface peaks in pore-water $\mathrm{NH}_{4}^{+}$at stations $6 \mathrm{~B}$ and 10 are likely a sampling artifact (Grandel et al., 2000 and references therein). With increasing water depth and BWO concentrations, the sediment depth to which $\mathrm{O}_{2}$ penetrates and dissolved $\mathrm{NO}_{3}^{-}$and $\mathrm{Mn}$ oxides persist increases (Table 7). Concurrently, peak concentrations of pore-water $\mathrm{Fe}^{2+}$ become lower and occur deeper in the sediment with increasing water depth (Fig. 4).

In general, the labile reactive $\mathrm{P}$ pools (organic $\mathrm{P}$ and $\mathrm{Fe}$ bound $\mathrm{P}$ ) record a down-core decrease at the investigated stations. The top $10 \mathrm{~cm}$ of sediment at station $1 \mathrm{~B}$ stands out in two ways: (i) a down-core increase in organic $\mathrm{P}$ and (ii) a strong enrichment in Fe-bound P. Only the OMZ stations 1B and 2 , where the highest $\mathrm{HPO}_{4}^{2-}$ concentrations were measured, record down-core increases in total reactive $\mathrm{P}$ and authigenic Ca-P (Fig. 5). The down-core enrichment of authigenic $\mathrm{Ca}-\mathrm{P}$ and concurrent decrease in pore-water $\mathrm{F}^{-}$are consistent with formation of the common marine apatite mineral carbonate fluorapatite, $\mathrm{Ca}_{5}\left(\mathrm{PO}_{4}, \mathrm{CO}_{3}\right)_{3} \mathrm{~F}$. A strong 


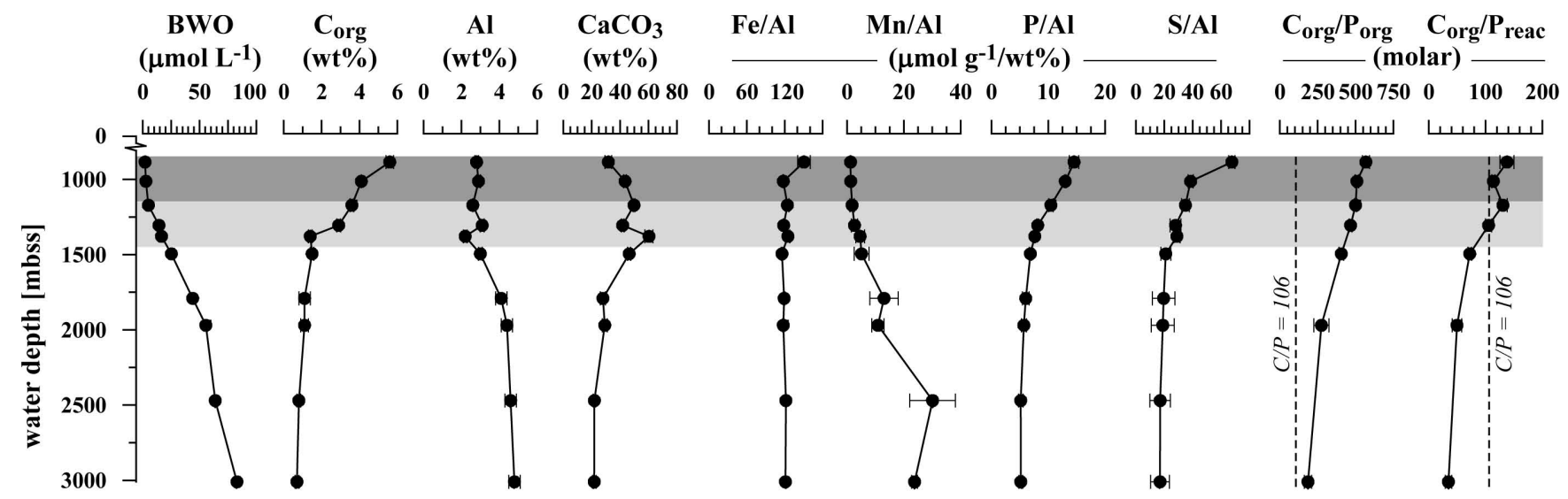

Fig. 3. Trends with water depth for bottom water oxygen (BWO) concentration and average total solid-phase $\mathrm{C}_{\mathrm{org}}$ content and $\mathrm{Al}$, Fe, $\mathrm{Mn}$, $\mathrm{P}$, $\mathrm{S}$ concentrations (normalized to $\mathrm{Al}$ ) in the top $2 \mathrm{~cm}$ of the sediment. Also included are the average molar organic $\mathrm{C} /$ organic $\mathrm{P}\left(\mathrm{C}_{\text {org }} / \mathrm{P}_{\text {org }}\right)$ and organic $\mathrm{C} /$ reactive $\mathrm{P}\left(\mathrm{C}_{\text {org }} / \mathrm{P}_{\text {reac }}\right)$ ratios in the top $2 \mathrm{~cm}$ for the selected stations for which sequential $\mathrm{P}$ extractions were performed. Dashed vertical lines indicate the C/P ratio of marine organic matter of 106 (Redfield, 1958). The dark grey area indicates the centre of the OMZ defined by $\mathrm{O}_{2}<\sim 4.5 \mu \mathrm{M}$; the light grey area indicates the extent of oxygen-depleted water up to the lower boundary of the OMZ defined by $\mathrm{O}_{2} \sim 22 \mu \mathrm{M}$ after Cowie and Levin (2009). Error bars indicate 1 standard deviation.

increase in the abundance of authigenic Ca-P is observed in the deeper sediments at station 2 and, to a lesser extent, station 1B. At the deeper stations 4, 6B and 10, authigenic Ca-P profiles are constant with sediment depth, while the decrease in Fe-bound $\mathrm{P}$ and organic $\mathrm{P}$ result in a down-core decrease in total reactive $\mathrm{P}$. Detrital $\mathrm{P}$ is a minor $\mathrm{P}$ pool at all stations that closely follows the authigenic Ca-P profiles, probably reflecting imperfect separation between authigenic and detrital $\mathrm{P}$ pools during the sequential $\mathrm{P}$ extractions.

The solid-phase Fe contents in the sediments from all stations show decreasing concentrations of total and reactive $\mathrm{Fe}$ with sediment depth (Fig. 6). The sediment profiles of total and reactive $\mathrm{Fe}$ are controlled by changes in the concentrations of labile and crystalline $\mathrm{Fe}$ (oxyhydr)oxides, which comprise the most important reactive $\mathrm{Fe}$ pool in the sediment. The concentrations of carbonate-associated $\mathrm{Fe}\left(\mathrm{Fe}_{\mathrm{carb}}\right)$ and $\mathrm{Fe}$ associated with $\mathrm{Fe}$ monosulfides $\left(\mathrm{Fe}_{\mathrm{AVS}}\right)$ were negligible at all stations. The sediments at all stations record a subsurface enrichment in labile Fe (oxyhydr)oxides, which is strongest in the top $10 \mathrm{~cm}$ at station 1B. Here, the high concentrations reveal a clear vertical separation between the peak in labile $\mathrm{Fe}$ (oxyhydr)oxides and crystalline $\mathrm{Fe}$ oxides, centred around $\sim 5$ and $8 \mathrm{~cm}$ depth, respectively. The peak in labile $\mathrm{Fe}$ (oxyhydr)oxides is similar to the peak in Febound $\mathrm{P}$ (Fig. 5). The dissolved $\mathrm{Fe}^{2+}$ profiles in sediments from the OMZ stations (1B, 2 and 4) show decreasing porewater $\mathrm{Fe}^{2+}$ concentrations at depth in the sediment. There is a strong increase in $\mathrm{Fe}_{\text {pyrite }}$ below $\sim 10 \mathrm{~cm}$ sediment depth at station 2 (Fig. 6), while there was very little pyrite observed in the sediments from the other stations.

\section{Reactive-transport model results for station 4}

The geochemical data indicated that station 4, located close to the lower boundary of the OMZ, represents an intermediate environment between the OMZ (station 2) and deeper, better oxygenated settings (stations $6 \mathrm{~B}$ and 10). We focused on this station in the modelling part of this study to further investigate early diagenesis and $\mathrm{P}$ cycling, and also in relation to BWO availability.

In general, the reactive-transport model (RTM) reproduces the depth profiles for most of the measured species at station 4 (Fig. 7). Pore-water $\mathrm{O}_{2}, \mathrm{NO}_{3}^{-}$and $\mathrm{Mn}$ oxides are rapidly consumed during the oxidation of labile $\mathrm{OM}$ and become depleted within the first few centimeters below the sediment surface. The concentration of Fe (oxyhydr)oxides is relatively constant in the top $3 \mathrm{~cm}$, below which these $\mathrm{Fe}$ phases undergo dissolution primarily through reaction with pore-water sulfide produced by sulfate reduction. A small fraction of the $\mathrm{Fe}$ (oxyhydr)oxides is dissolved by dissimilatory Fe reduction. At depth, there remains a background concentration of more recalcitrant $\mathrm{Fe}$ (oxyhydr)oxides and associated Fe-P. Sulfate reduction rates (SRRs) are not sufficient to deplete pore-water $\mathrm{SO}_{4}^{2-}$, which shows only a very slight decrease with depth. Quantification of the depth-integrated rates of OM decomposition shows that oxic respiration and nitrification are the dominant processes (together accounting for $89 \%$ of OM decomposition), with a relatively minor contribution of $10 \%$ by sulfate reduction (Fig. 8). Dissimilatory reduction of $\mathrm{Fe}$ (oxyhydr)oxides and $\mathrm{Mn}$ oxides and methanogenesis play negligible roles, together accounting for $\sim 1 \%$ of OM decomposition.

The model captures the accumulation of pore-water $\mathrm{NH}_{4}^{+}$ resulting from $\mathrm{OM}$ decomposition (Fig. 7). In the model, the 


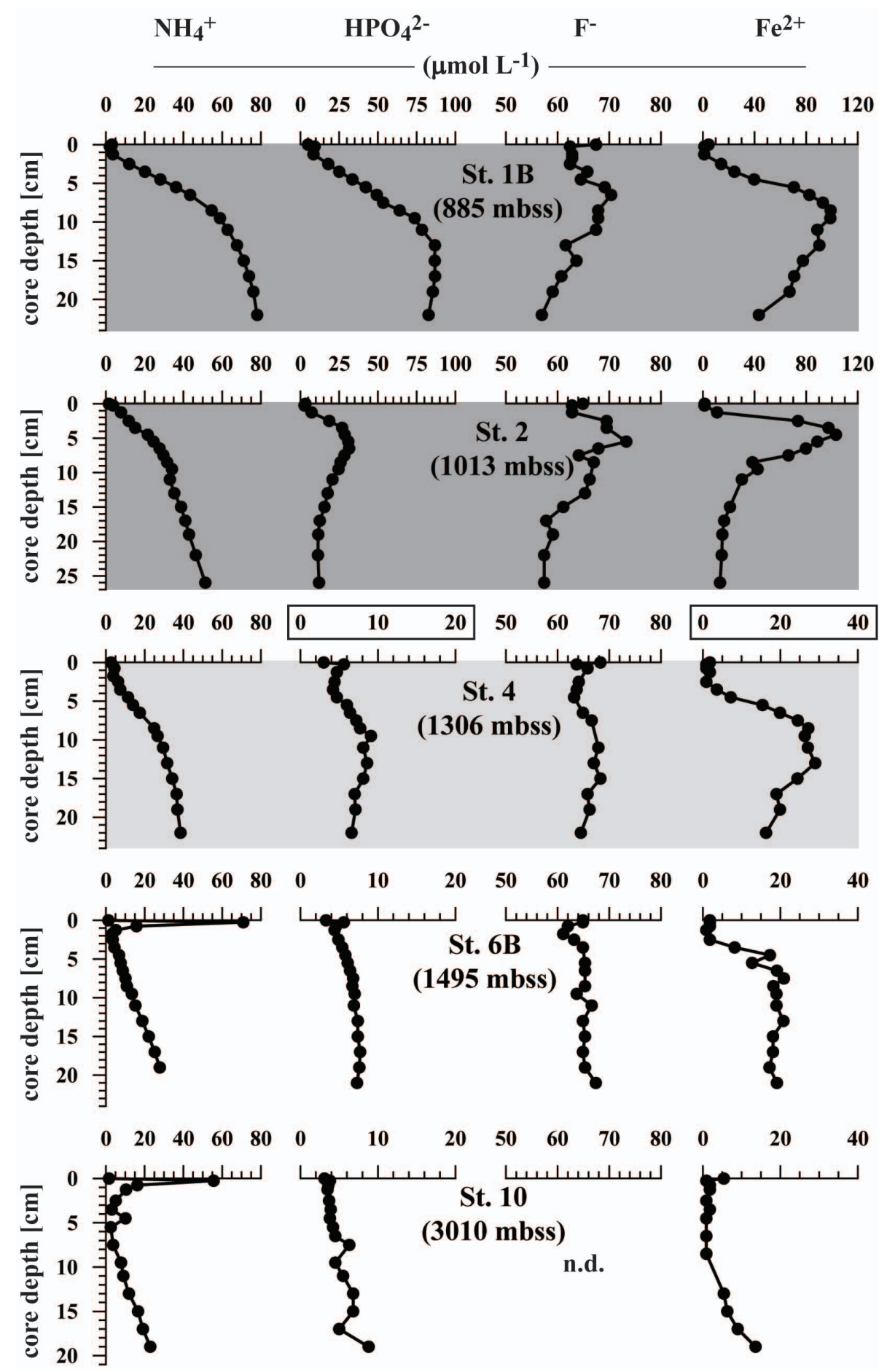

Fig. 4. Pore-water $\mathrm{NH}_{4}^{+}, \mathrm{HPO}_{4}^{2-}, \mathrm{F}^{-}$and $\mathrm{Fe}^{2+}$ concentrations in the cores from stations $1 \mathrm{~B}, 2,4,6 \mathrm{~B}$ and 10 . Note the different $\mathrm{x}$-axis scale for $\mathrm{HPO}_{4}^{2-}$ and $\mathrm{Fe}^{2+}$ for stations 4, 6B and 10. mbss = meters below sea surface; n.d. = not determined. Dark and light grey fills indicate station position: core of the OMZ, stations 1B and 2 (dark grey), lower boundary of the OMZ, station 4 (light grey). See caption to Fig. 3 for details on OMZ definition. The graphs for stations $6 \mathrm{~B}$ and 10 below the OMZ have no fill.

low $\mathrm{NH}_{4}^{+}$concentration in the top $\sim 4 \mathrm{~cm}$ of the sediment is controlled by nitrification. Anaerobic ammonium oxidation, for which molecular fossil evidence has been found in the northern Arabian Sea (Jaeschke et al., 2009), was not included in the model. 


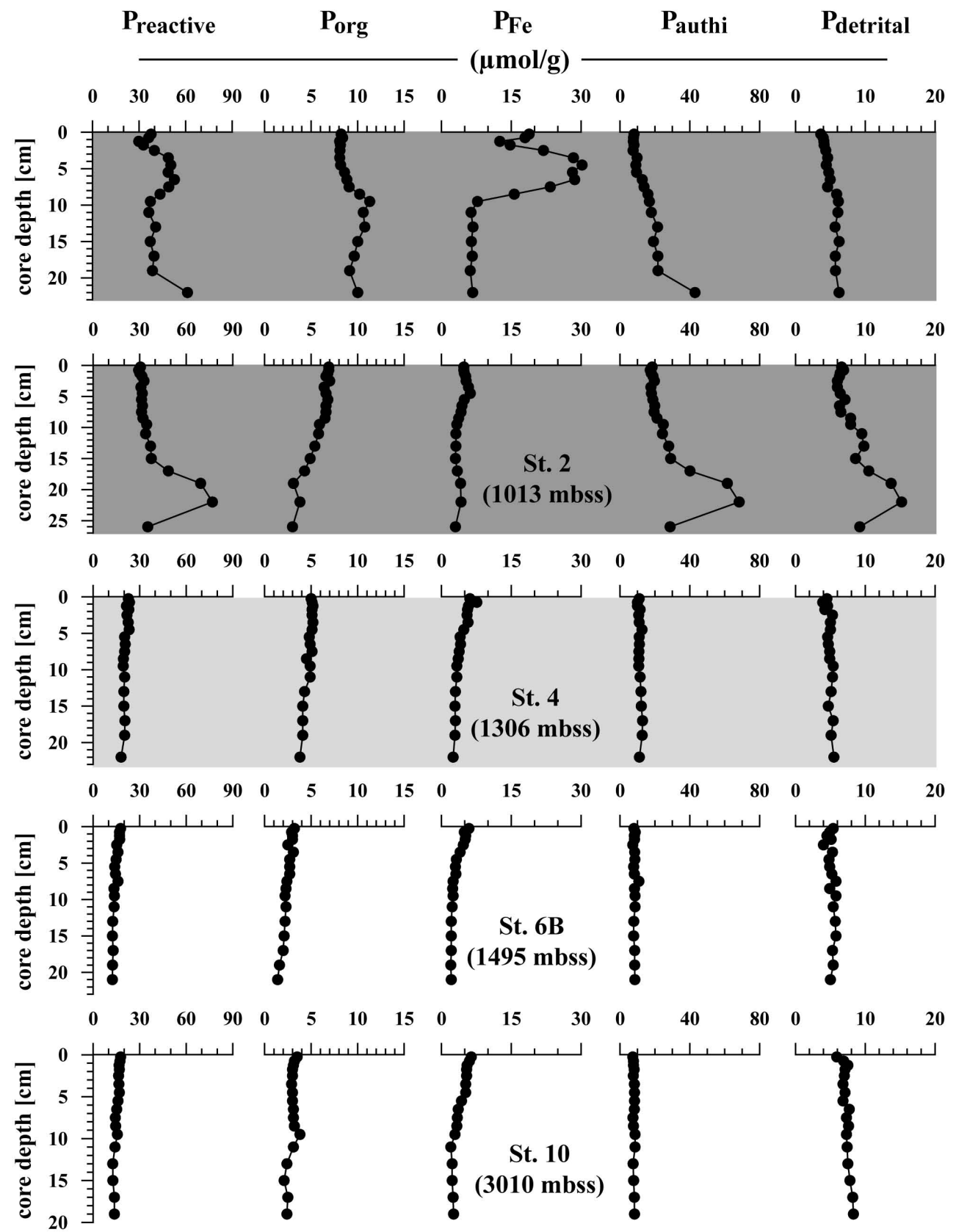

Fig. 5. Phosphorus speciation in the cores from stations $1 B, 2,4,6 \mathrm{~B}$ and 10 as determined by sequential extraction: total reactive $P\left(P_{\text {reactive }}\right)$ calculated as total $\mathrm{P}$ - detrital $\mathrm{P}, \mathrm{Fe}$-bound $\mathrm{P}\left(\mathrm{P}_{\mathrm{Fe}}\right)$, authigenic Ca-P $\left(\mathrm{P}_{\text {authi }}\right)$, detrital $\mathrm{P}\left(\mathrm{P}_{\text {det }}\right)$, and organic $\mathrm{P}\left(\mathrm{P}_{\mathrm{org}}\right)$. Exchangeable $\mathrm{P}$ was negligible in all cores and is therefore not shown. Fill colours indicate station position as detailed in the caption to Fig. 4.

Pore-water $\mathrm{Fe}^{2+}$ and, to a lesser extent, $\mathrm{HPO}_{4}^{2-}$ are underestimated by the RTM (Fig. 7). More specifically, the RTM did not reproduce the peaks in pore-water $\mathrm{Fe}^{2+}$ and $\mathrm{HPO}_{4}^{2-}$ concentrations centred around $\sim 10 \mathrm{~cm}$ sediment depth. Given that these peaks are located below the bioturbated surface layer, short-term temporal changes in downward mixing of $\mathrm{Fe}$ (oxyhydr)oxides and subsequent release of $\mathrm{Fe}^{2+}$ and $\mathrm{HPO}_{4}^{2-}$ (Slomp et al., 1996a) is unlikely. A pos- sible explanation is that the reductive dissolution of more crystalline $\mathrm{Fe}$ oxides $\left(\mathrm{Fe}_{\mathrm{ox} 2}\right.$ in the $\mathrm{Fe}$ fractionation procedure) that may act as a deep source of $\mathrm{Fe}^{2+}$ and $\mathrm{HPO}_{4}^{2-}$ is underestimated in the model. The results of the $\mathrm{Fe}$ fractionation procedure $\left(\mathrm{Fe}_{\mathrm{ox} 1}+\mathrm{Fe}_{\mathrm{ox} 2}\right.$, Fig. 7) indicate that there is an appreciable pool of more crystalline $\mathrm{Fe}$ oxides that withstood dissolution during the SEDEX extraction step for $\mathrm{P}$ and $\mathrm{Fe}$ in easily reducible $\mathrm{Fe}$ (oxyhydr)oxides $\left(\mathrm{Fe}_{\mathrm{CDB}}\right.$, Fig. 7). 


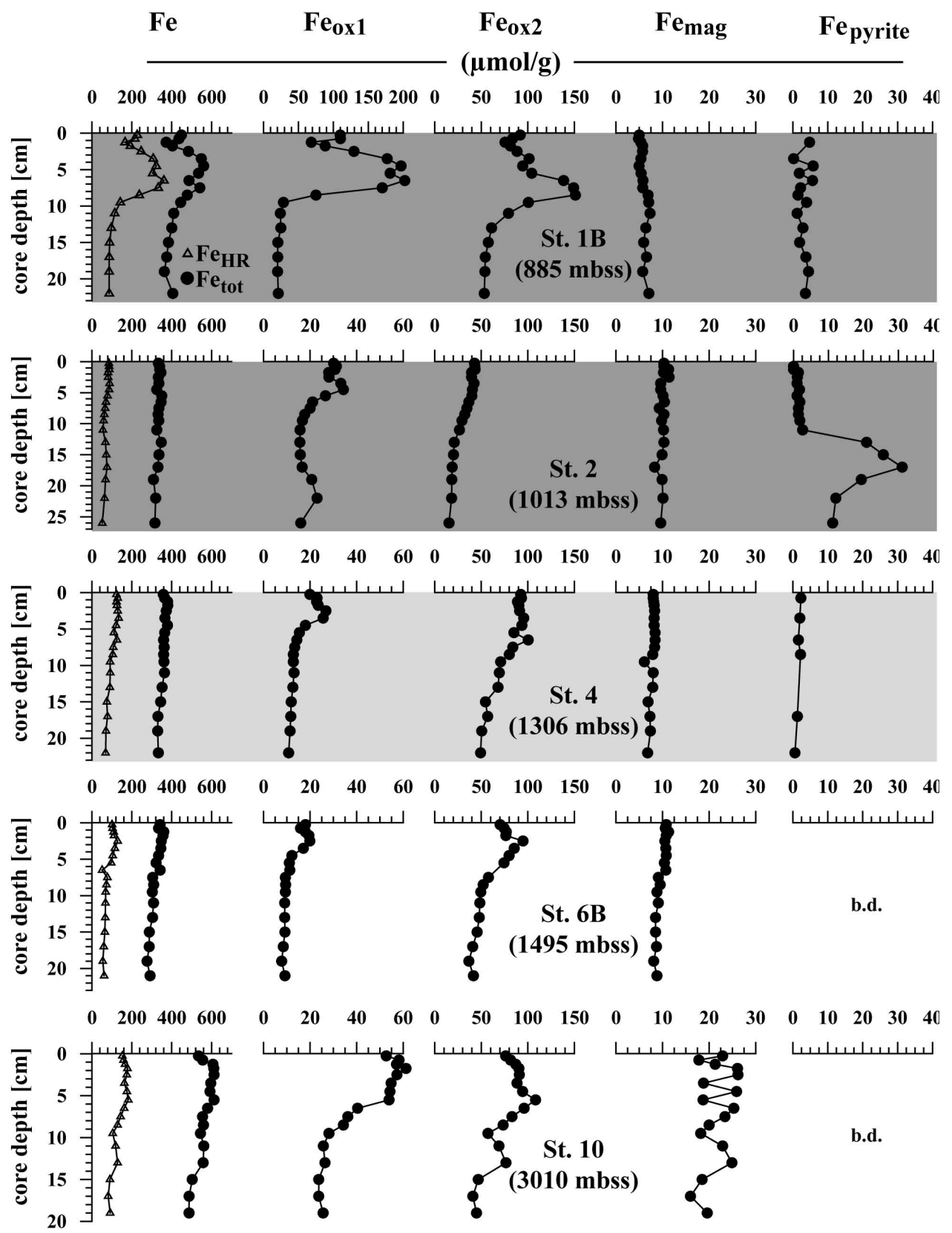

Fig. 6. Iron speciation in the cores from stations $1 \mathrm{~B}, 2,4,6 \mathrm{~B}$ and 10 determined by sequential extraction: total $\mathrm{Fe}(\mathrm{Fe}$ tot $)$, highly reactive $\mathrm{Fe}\left(\mathrm{Fe}_{\mathrm{HR}}\right)$ calculated as the sum of all non-detrital Fe phases: poorly crystalline $\mathrm{Fe}$ (oxyhydr)oxides $\left(\mathrm{Fe}_{\mathrm{ox} 1}\right)$, crystalline $\mathrm{Fe}$ (oxyhydr)oxides $\left(\mathrm{Fe}_{\mathrm{ox} 2}\right)$, recalcitrant $\mathrm{Fe}$ oxides (mainly magnetite, $\mathrm{Fe}_{\mathrm{mag}}$ ), and $\mathrm{Fe}$ in pyrite $\left(\mathrm{Fe}_{\text {pyrite }}\right)$. b.d. = below the detection limit. Carbonate-associated $\mathrm{Fe}$ was negligible in all cores and is therefore not shown. Fill colours indicate station position as detailed in the caption to Fig. 4.

Crystalline Fe oxides commonly contain small amounts of bound $\mathrm{P}$ compared to more reactive fresh $\mathrm{Fe}$ oxyhydroxides (Slomp et al., 1996b). This may explain why the model underestimates the peak of pore-water $\mathrm{Fe}^{2+}$ much more than that of $\mathrm{HPO}_{4}^{2-}$.

Using the original rate constant of $\sim 1500$ (Reed et al., 2011b) for the reaction between pore-water $\mathrm{Fe}^{2+}$ and $\mathrm{H}_{2} \mathrm{~S}$ (R17 in Table 4) led to an appreciable mismatch between the model results and the experimental data. In the model, pore-water $\mathrm{Fe}^{2+}$ became depleted throughout the model domain ( $0-27 \mathrm{~cm}$ sediment depth), $\mathrm{H}_{2} \mathrm{~S}$ concentrations reached $\sim 60 \mu \mathrm{mol} \mathrm{L} \mathrm{L}^{-1}$ at depth, and a considerable amount of $\mathrm{FeS}_{2}\left(\sim 25 \mu \mathrm{mol} \mathrm{g}{ }^{-1}\right)$ was produced. These results contrasted with the experimental data that showed abundant pore-water $\mathrm{Fe}^{2+}$ (Fig. 4), but low pore-water $\mathrm{H}_{2} \mathrm{~S}$ concentrations $\left(<1 \mu \mathrm{mol} \mathrm{L}{ }^{-1}\right.$, data not shown) and small amounts 
of $\mathrm{FeS}_{2}$ in the sediment (Fig. 7). Loss of $\mathrm{H}_{2} \mathrm{~S}$ from the pore-water during sample preparation and handling may have slightly decreased pore-water $\mathrm{H}_{2} \mathrm{~S}$ in the experimental results, but cannot account for all the above-described disparities between Fe-S chemistry in the model results and experimental data. To reconcile the differences between model output and experimental results, the rate constant for the reaction between pore-water $\mathrm{Fe}^{2+}$ and $\mathrm{H}_{2} \mathrm{~S}$ was set to 1 . The implications are further described in Sect. 6.3.

The model overestimates the concentration of organic $\mathrm{P}$ in the top sediment. A possible explanation is that using the Redfield C/P ratio (106/1) for the highly reactive OM pool results in overestimating its actual $\mathrm{P}$ content, as reactive $\mathrm{OM}$ may be a mixture of fresh algal matter and more degraded organic material. The RTM successfully captures the depth profile of authigenic Ca-P at station 4. To investigate the importance of $\mathrm{Fe}$ redox cycling to sedimentary $\mathrm{P}$ cycling, an RTM run without deposition of reactive Fe (oxyhydr)oxides was performed. The vertical authigenic Ca-P profile (dashed line in lower right panel, Fig. 7) resulting from this test run illustrates the essential role that $\mathrm{HPO}_{4}^{2-}$ scavenging by $\mathrm{Fe}$ (oxyhydr)oxides in the top layer of the sediment and subsequent release of $\mathrm{HPO}_{4}^{2-}$ at depth play in accumulation of pore-water $\mathrm{HPO}_{4}^{2-}$ and authigenic Ca-P formation. Without this mechanism, the only source of sedimentary $\mathrm{Ca}-\mathrm{P}$ in the RTM is deposition of unreactive Ca-P at the sediment-water interface. Importantly, the model captures both dissolved and solid-phase $\mathrm{P}$ profiles without including fish debris, indicating that this $\mathrm{P}$ pool plays only a minor role in $\mathrm{P}$ cycling at station 4.

The RTM allows a depth-integrated $(27 \mathrm{~cm})$ quantitative investigation of sedimentary P cycling at station 4 (Fig. 9). Organic $\mathrm{P}$ is the main reactive $\mathrm{P}$ source to the sediment, with relatively minor contributions of $\mathrm{P}$ associated with reactive and recalcitrant $\mathrm{Fe}$ (oxyhydr)oxides. A relatively large background flux of $\mathrm{Ca}-\mathrm{P}$ is required to account for the measured authigenic $\mathrm{Ca}-\mathrm{P}$ concentrations in the sediment; $\mathrm{P}$ authigenesis contributes only a small fraction $(15 \%)$ to total Ca-P burial below $27 \mathrm{~cm}$ depth. The Ca-P pool that is delivered from the water column in the RTM is unreactive in the sediment. The total burial efficiency (total BE) of $\mathrm{P}$ that reaches the sediment surface can be calculated from the total $\mathrm{P}$ input and total $\mathrm{P}$ burial:

Total $\mathrm{BE}=100^{*}\left(\mathrm{P}_{\mathrm{org}}+\mathrm{P}_{\mathrm{Fe}}+\mathrm{Ca}-\mathrm{P}\right)_{\mathrm{BURIAL}} /$

$\left(\mathrm{P}_{\text {org }}+\mathrm{P}_{\mathrm{Fe}}+\mathrm{Ca}-\mathrm{P}\right)_{\text {INPUT }}$

In addition, the burial efficiency of reactive $\mathrm{P}$ (reactive $\mathrm{BE}$ ) can be obtained from the input and burial of truly reactive $P$ phases. Iron-bound $\mathrm{P}$ at depth is considered recalcitrant and not included in the reactive $\mathrm{P}$ pool. Furthermore, the Ca-P formation rate in the sediment (P authigenesis in Fig. 9) represents the burial flux of truly authigenic Ca-P:

Reactive $\mathrm{BE}=100^{*}\left(\left(\mathrm{P}_{\text {org }}\right)_{\mathrm{BURIAL}}+\mathrm{P}\right.$ authigenesis $) /$

$\left(\mathrm{P}_{\text {org }}+\mathrm{P}_{\mathrm{Fe}}\right)_{\text {INPUT }}$
The total $\mathrm{BE}$ is $14 \%$ and the reactive $\mathrm{BE}$ is $6 \%$ (with $3 \%$ as authigenic $\mathrm{Ca}-\mathrm{P}$ and $3 \%$ in $\mathrm{OM}$ ), which shows the potential importance of the contribution of unreactive $\mathrm{P}$ phases that are delivered from the water column to total $\mathrm{P}$ burial. The higher total BE is almost exclusively attributable to the unreactive $\mathrm{Ca}-\mathrm{P}$ pool deposited from the water column. Finally, the RTM output shows that the efficiency with which P released from organic matter deposited at the sediment surface is transformed into stable authigenic Ca-P, destined for long-term burial, is only $\sim 3 \%$.

\section{Discussion}

\subsection{Phosphorus cycling in the northern Arabian Sea}

The results indicate that $\mathrm{P}$ authigenesis is mostly restricted to the OMZ in the northern Arabian Sea, which complies with earlier work in this area (Schenau and De Lange, 2001). The solid phase $(\mathrm{Ca}-\mathrm{P})$ and pore-water $\left(\mathrm{HPO}_{4}^{2-}, \mathrm{F}^{-}\right)$profiles at stations $1 \mathrm{~B}$ and 2 in the heart of the OMZ reflect the precipitation of carbonate fluorapatite, resulting in a downward increase in authigenic Ca-P and total reactive $\mathrm{P}$. In the heart of the OMZ, P sink switching from labile reactive OM and $\mathrm{Fe}$ (oxyhydr)oxides to Ca-P minerals plays an important role in long-term $\mathrm{P}$ sequestration. At the deeper stations $(4,6 \mathrm{~B}$ and 10), the more or less constant $\mathrm{Ca}-\mathrm{P}$ depth profiles reflect the limited role of Ca-P authigenesis in $\mathrm{P}$ cycling. Here, the in-situ formation of Ca-P minerals plays only a minor role in sequestering $\mathrm{P}$ released from labile sedimentary pools.

Iron redox cycling can play an important role in sedimentary $\mathrm{P}$ cycling in the OMZ. At station 1B, the abundant $\mathrm{Fe}$ (oxyhydr)oxides in the surface sediments scavenge upward diffusing pore-water $\mathrm{HPO}_{4}^{2-}$, leading to a strong enrichment of Fe-bound $\mathrm{P}$ in the shallow sediments (Fig. 6). Deeper burial and reductive dissolution of these $\mathrm{Fe}$ (oxyhydr)oxides act to enhance pore-water $\mathrm{HPO}_{4}^{2-}$ concentrations and authigenic Ca-P formation. Such a shallow enrichment of $\mathrm{Fe}$ (oxyhydr)oxides has also been observed in sediments from similar depth and with a similar BWO concentration ( $998 \mathrm{mbss},<2 \mu \mathrm{mol} \mathrm{O} \mathrm{L}^{-1}$ ) on the Pakistan continental slope (Schenau and De Lange, 2001). It likely results from subsurface precipitation of $\mathrm{Fe}^{2+}$ that diffuses upward from the deeper, reducing sediment. The Fe enrichment at station $1 \mathrm{~B}$ is largely confined to $\sim 2$ and $10 \mathrm{~cm}$ sediment depth, which suggests that it reflects a transient change in bottom water redox conditions. In this respect, the co-occurrence of high pore-water $\mathrm{Fe}^{2+}$ concentrations and abundant $\mathrm{Fe}$ (oxyhydr)oxides between $\sim 5-10 \mathrm{~cm}$ sediment depth also indicates that the sediment and pore-water at station $1 \mathrm{~B}$ are not in steady state. It remains unclear how common temporal changes in benthic conditions are in the OMZ and the extent of their role in $\mathrm{P}$ cycling. Station 2 has a slightly higher BWO concentration $\left(\sim 3 \mu \mathrm{mol} \mathrm{O}_{2} \mathrm{~L}^{-1}\right)$ than station $1 \mathrm{~B}$, but subsurface $\mathrm{Fe}$ (oxyhydr)oxides are much less abundant and 

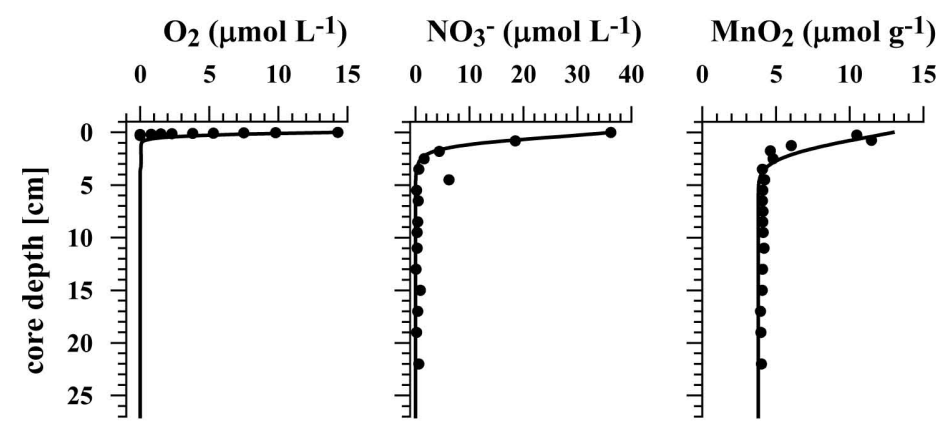

$\mathrm{Fe}_{\text {ox }}\left(\mu \mathrm{mol} \mathrm{g}^{-1}\right)$

$\begin{array}{llll}0 & 50 & 100 & 150\end{array}$
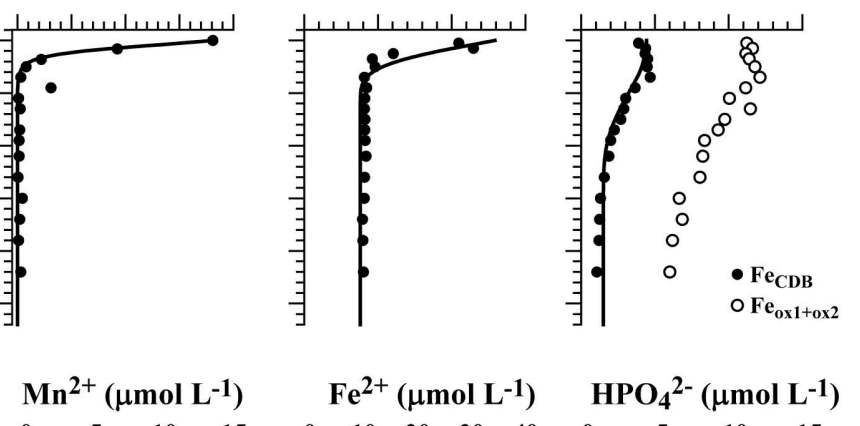

(0) 10 20
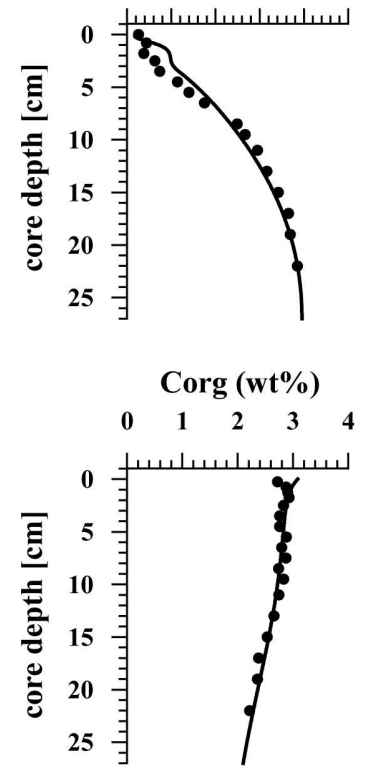
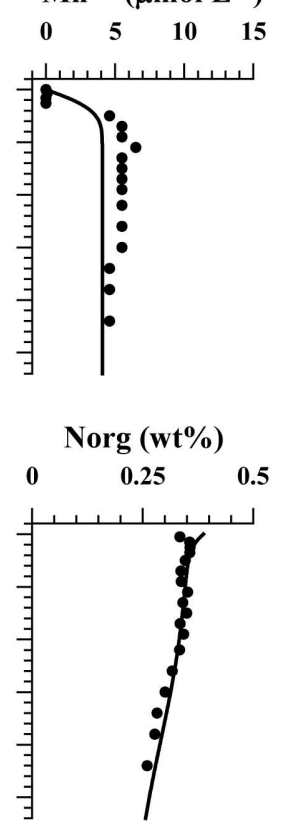

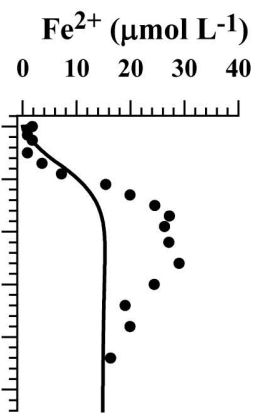

Porg $\left(\mu \mathrm{mol} \mathrm{g}{ }^{-1}\right)$

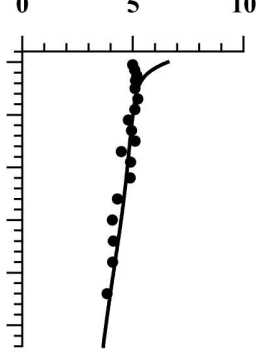

$\mathrm{HPO}_{4}{ }^{2-}\left(\mu \mathrm{mol} \mathrm{L}{ }^{-1}\right)$
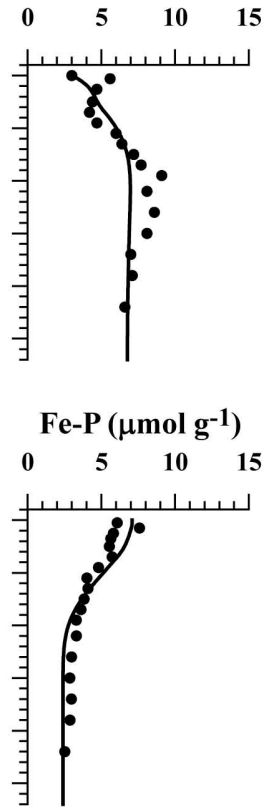

$\mathrm{SO}_{4}{ }^{2-}\left(\mathrm{mmol} \mathrm{L}^{-1}\right)$

$\begin{array}{llll}20 & 25 & 30 & 35\end{array}$

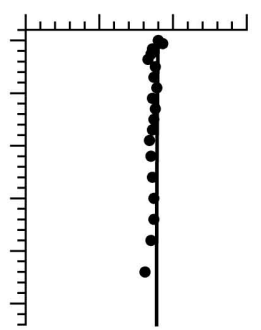

$\mathrm{FeS} / \mathrm{FeS}_{2}\left(\mu \mathrm{mol} \mathrm{g^{-1 }}\right)$

$\begin{array}{llll}0 & 5 & 10 & 15\end{array}$

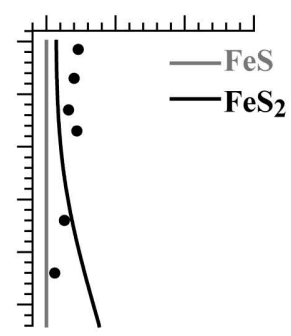

authi-P $\left(\mu \mathrm{mol} \mathbf{g}^{-1}\right)$

$\begin{array}{lllll}0 & 5 & 10 & 15 & 20\end{array}$

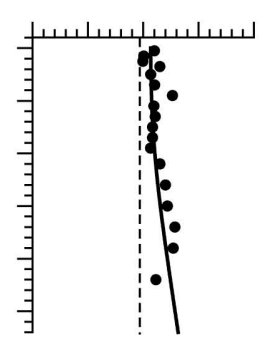

Fig. 7. Steady state RTM output (solid lines) and experimental data (black points) for station 4. Upper panel shows profiles of electron acceptors for $\mathrm{OM}$ degradation: dissolved $\mathrm{O}_{2}, \mathrm{NO}_{3}^{-}$, Mn oxides $\left(\mathrm{MnO}_{2}\right)$ and $\mathrm{Fe}$ (oxyhydr)oxides $\left(\mathrm{Fe}_{\mathrm{ox}}\right.$, the easily reducible Fe (oxyhydr)oxides determined by sequential chemical extraction). Middle panel shows pore-water profiles of species released by organic matter degradation $\left(\Sigma \mathrm{NH}_{4}^{+}\left(\mathrm{NH}_{4}^{+}+\mathrm{NH}_{3}^{+}\right), \mathrm{HPO}_{4}^{2-}\right)$ and reductive dissolution of metal oxides $\left(\mathrm{Mn}^{2+}, \mathrm{Fe}^{2+}, \mathrm{HPO}_{4}^{2-}\right)$, and reduced FeS species. Lower panel shows profiles of organic $\mathrm{C}\left(\mathrm{C}_{\text {org }}\right)$ and $\mathrm{N}\left(\mathrm{N}_{\text {org }}\right)$ and organic $\mathrm{P}\left(\mathrm{P}_{\text {org }}\right)$, Fe-bound $\mathrm{P}\left(\mathrm{P}_{\mathrm{Fe}}\right)$ and authigenic Ca-P $\left(\mathrm{P}_{\text {authi }}\right)$. The vertical dashed line in the $\mathrm{P}_{\text {authi }}$ plot indicates the authigenic Ca-P concentration in a model run without deposition of reactive Fe (oxyhydr)oxides.

Fe-bound $\mathrm{P}$ is only a minor, relatively stable $\mathrm{P}$ phase throughout the core (Fig. 5). This shows that in the OMZ the deposition and decomposition of labile $\mathrm{P}$ phases and subsequent pore-water $\mathrm{HPO}_{4}^{2-}$ accumulation can suffice in triggering authigenic $\mathrm{Ca}-\mathrm{P}$ formation without an intermediate role for $\mathrm{Fe}$ redox cycling. The $\mathrm{P}$ enrichment between $\sim 15$ and $26 \mathrm{~cm}$ core depth possibly represents a past period with increased deposition of labile $\mathrm{P}$ phases and enhanced authigenic Ca-P formation. This seems to be reflected in the sediment at station 1B as well, where the deepest sample records an increase in $\mathrm{P}$ contents.

The RTM results for station 4 show that Fe redox cycling is crucial to authigenic Ca-P formation at this intermediate location around the lower boundary of the OMZ. Only through binding of $\mathrm{HPO}_{4}^{2-}$ to $\mathrm{Fe}$ (oxyhydr)oxides in surface sediments and release at depth do pore-water $\mathrm{HPO}_{4}^{2-}$ concentrations reach levels sufficiently high to trigger apatite precipitation. At the deeper stations 6B and 10, Fe-bound P is an important $\mathrm{P}$ phase in the surface sediment, accounting for $\sim 25 \%$ of total $\mathrm{P}$, but authigenic Ca-P formation is limited by the low pore-water $\mathrm{HPO}_{4}^{2-}$ concentrations (Figs. 4 and 5). The finding that Fe redox cycling can play an important role in $\mathrm{P}$ authigenesis and sequestration in sediments from the lower part of the OMZ contrasts with earlier experimental studies that have assumed a limited significance of Fe-bound $\mathrm{P}$ in the sedimentary $\mathrm{P}$ budget of the Arabian Sea, especially for oxygen-depleted conditions (Schenau et al., 2000; Prakash Babu and Nath, 2005).

The P/Al ratio in surface sediments along the depth transect (Fig. 3) and the authigenic Ca-P profiles (Fig. 5) reflect 


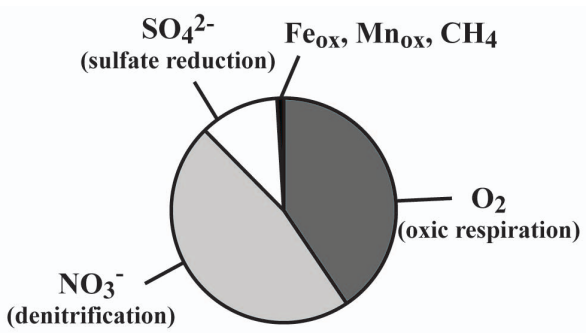

OM degradation pathways
oxic respiration: $\quad 8.6 \mu \mathrm{mol} \mathrm{C} \mathrm{Corg}_{\text {om }} \mathrm{cm}^{-2} \mathrm{y}^{-1}(41 \%)$
denitrification: $\quad 9.9 \mu \mathrm{mol} \mathrm{C} \mathrm{org} \mathrm{cm}^{-2} \mathrm{y}^{-1}(47 \%)$
sulfate reduction: $2.4 \mu \mathrm{mol} \mathrm{C} \mathrm{org}_{\mathrm{og}} \mathrm{cm}^{-2} \mathrm{y}^{-1}(11 \%)$
other: $\quad 0.2 \mu \mathrm{mol} \mathrm{C}_{\text {org }} \mathrm{cm}^{-2} \mathrm{y}^{-1}(1 \%)$

Fig. 8. Quantification of organic matter degradation pathways (as depth-integrated rates) in the sediments from station 4: oxic respiration $\left(\mathrm{O}_{2}\right)$, denitrification $\left(\mathrm{NO}_{3}^{-}\right)$and sulfate reduction $\left(\mathrm{SO}_{4}^{2-}\right)$. The numbers represent organic $\mathrm{C}$ degradation rates in $\mu \mathrm{mol} \mathrm{cm}{ }^{-2} \mathrm{yr}^{-1}$, with the relative contribution to total degradation between parentheses. Organic matter decomposition by dissimilatory reduction of $\mathrm{Fe}$ (oxyhydr)oxides and Mn oxides and by methanogenesis are combined and referred to as "other".

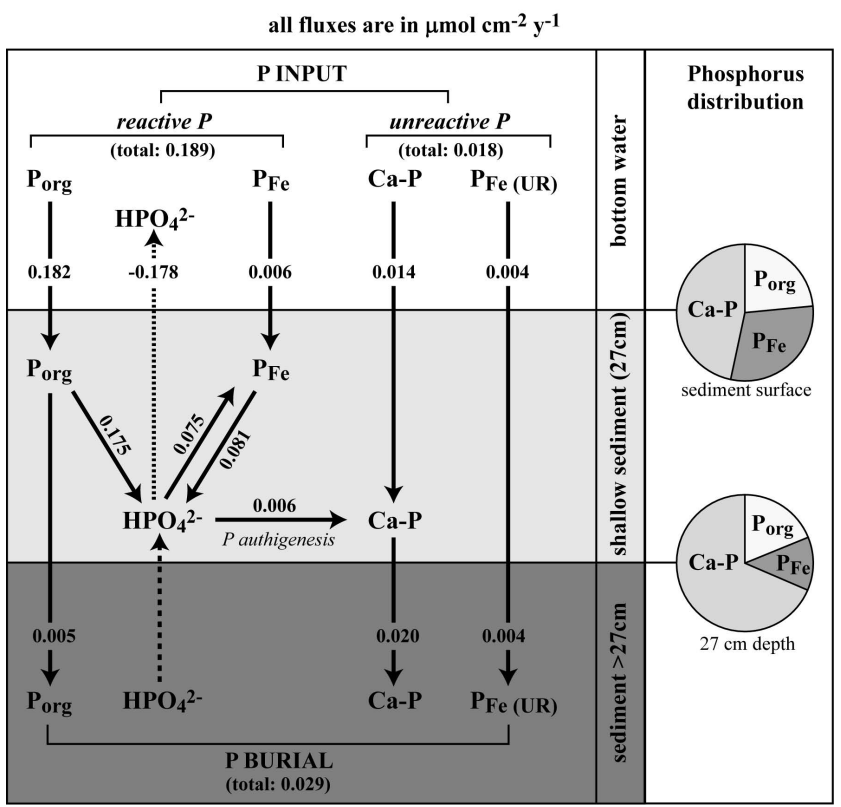

Fig. 9. Phosphorus budget for station 4, including organic $\mathrm{P}\left(\mathrm{P}_{\mathrm{org}}\right)$, reactive Fe-bound $\mathrm{P}\left(\mathrm{P}_{\mathrm{Fe}}\right)$ and $\mathrm{P}$ bound to unreactive $\mathrm{Fe}$ (oxyhydr)oxides $\left(\mathrm{P}_{\mathrm{Fe}}(\mathrm{UR})\right.$ ) and $\mathrm{Ca}-\mathrm{P}$. All fluxes are in $\mu \mathrm{mol} \mathrm{cm} \mathrm{cm}^{-2} \mathrm{yr}^{-1}$. Phosphorus input is the total depositional flux of $\mathrm{P}$ at the sediment-water interface. The $\mathrm{HPO}_{4}^{2-}$ efflux is the net sum of diffusion, bioirrigation and boundary exchange. The right panel shows the modelled diagenetic changes in sedimentary $\mathrm{P}$ speciation with depth.

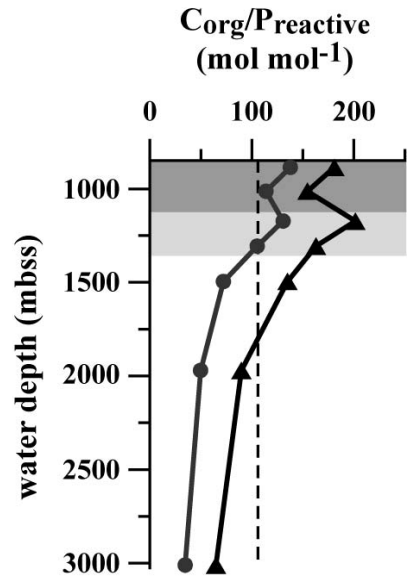

Fig. 10. The $\mathrm{C}_{\text {org }} / \mathrm{P}_{\text {reactive }}$ ratio along the depth transect. The grey line shows the ratio as calculated from total $\mathrm{C}_{\text {org }}$ and total reactive $\mathrm{P}$ determined by sequential extraction, where the latter likely overestimates reactive $\mathrm{P}$ burial as refractory $\mathrm{Ca}-\mathrm{P}$ is included in the reactive $\mathrm{P}$ budget (see text for details). The black line show the corrected $\mathrm{C}_{\text {org }} / \mathrm{P}_{\text {reactive }}$ ratio, where background $\mathrm{Ca}-\mathrm{P}$ is subtracted from the authigenic Ca-P pool. The vertical dashed line indicates the Redfield $\mathrm{C} / \mathrm{P}$ ratio of organic matter of 106 . The dark and light grey areas indicate the core and lower boundary of the $\mathrm{OMZ}$ as detailed in the caption to Fig. 3.

increased $\mathrm{P}$ authigenesis and $\mathrm{P}$ burial in the OMZ. At the same time, the upward increase in the $\mathrm{C}_{\text {org }} / \mathrm{P}_{\text {org }}$ and $\mathrm{C}_{\text {org }} / \mathrm{P}_{\text {reactive }}$ ratios from the deep sea to the OMZ indicates that with decreasing BWO concentrations, preferential $\mathrm{P}$ release from $\mathrm{OM}$ increases and the overall $\mathrm{P}$ retention efficiency in the sediment decreases. Increased $\mathrm{P}$ burial in sediments that less efficiently retain $\mathrm{P}$ suggests that changes in the magnitude of the depositional fluxes along the depth transect must play an important role in sedimentary $\mathrm{P}$ cycling. With increasing water depth, the extent of OM degradation and remineralization in the water column increases, especially in the better oxygenated water below the OMZ. This leads to a decline in $\mathrm{OM}$ and reactive $\mathrm{P}$ deposition with increasing water depth (Suthhof et al., 2000; Schenau and De Lange, 2001). This negatively affects accumulation of $\mathrm{HPO}_{4}^{2-}$ in the pore-water and subsequent authigenic Ca-P formation. This fits well with a recent modelling study that showed that $\mathrm{P}$ authigenesis is enhanced by high OM fluxes, both under low and high oxygen concentrations in the bottom waters (Tsandev et al., 2010). Our results confirm that $\mathrm{P}$ abundance and $\mathrm{C}_{\text {org }}$ to $\mathrm{P}$ ratios can be used as indicators of changes in productivity and the extent of the OMZ in the Arabian Sea (Schenau et al., 2005).

\subsection{Reactivity and burial efficiency of phosphorus pools}

The $\mathrm{C}_{\mathrm{org}} / \mathrm{P}_{\text {reactive }}$ ratio increases from well below to slightly above the Redfield ratio for fresh organic matter (106/1) with decreasing water depth and BWO concentrations (Fig. 3), 
suggesting overall efficient sedimentary sequestration of $\mathrm{P}$. However, using this ratio to assess burial efficiency is based on the assumption that all $\mathrm{P}$ is initially delivered to the sediment in $\mathrm{OM}$, where $\mathrm{P}$ undergoes diagenetic redistribution. Our results suggest that this assumption may not hold for all marine settings. The RTM output shows that a large part of the sedimentary Ca-P may in fact be directly deposited from the water column (see Sect. 5, Fig. 9). The experimental data also provide evidence for the deposition of unreactive $\mathrm{Ca}-\mathrm{P}$ : the surface sediments (top $2 \mathrm{~cm}$ ) from stations $1 \mathrm{~B}, 6 \mathrm{~B}$ and 10 along the depth transect all contain similar concentrations of "authigenic" Ca-P $\left(7.9 \pm 0.4 \mu \mathrm{mol} \mathrm{g}^{-1}, n=3\right)$. The stability of the background Ca-P pool in surface sediments across the depth transect and the constant depth profiles of $\mathrm{Ca}-\mathrm{P}$ in the sediments from stations $4,6 \mathrm{~B}$ and 10 suggest that it is unlikely that this $\mathrm{P}$ is in reactive form such as fish debris. Deposition of fish debris (i.e. hydroxyapatite) has been suggested to play an important role in authigenic Ca-P formation in the Arabian Sea (Schenau and De Lange, 2001; Schenau et al., 2005). Due to its labile nature, fish debris can undergo rapid dissolution and contribute to pore-water $\mathrm{HPO}_{4}^{2-}$ accumulation and subsequent authigenic Ca-P formation. Our results, however, suggest a limited role for fish debris in the sedimentary $\mathrm{P}$ cycle, at least at station 4 in the lower boundary of the OMZ. Pore-water $\mathrm{HPO}_{4}^{2-}$ concentrations and authigenic Ca-P formation at station 4 are accurately represented by the model which does not account for the deposition of labile fish debris. However, our model results cannot preclude a more prominent role for fish debris deposition in P cycling in sediments underlying the core of the OMZ. The deposition of the unreactive Ca-P at the sediment surface may result from atmospheric input of Ca-P minerals in dust (Eijsink et al., 2000; Palastanga et al., 2011) or authigenic Ca-P formation in the water column (Faul et al., 2005). The Arabian Sea receives relatively large fluxes of $\mathrm{P}$ through atmospheric input (Okin et al., 2011). In addition, fish debris may be less reactive than previously assumed and thus contribute to the background Ca-P pool.

The contribution of dust deposition to Ca-P burial can be approximated with measured lithogenic mass fluxes in the Arabian Sea and the Ca-P content of lithogenic material. Using a lithogenic mass flux of $6 \mathrm{~g} \mathrm{~m}^{-2} \mathrm{y}^{-1}$ to the Arabian Sea floor derived from sediment trap data in the western Arabian Sea (Haake et al., 1993; Ramaswamy and Nair, 1994; Honjo et al., 1999) and an authigenic Ca-P concentration of $12 \mu \mathrm{mol} \mathrm{g}^{-1}$ in dust (Eijsink et al., 2000), $\sim 60 \%$ of the background Ca-P concentration (estimated at a depthindependent concentration of $\sim 8 \mu \mathrm{mol} \mathrm{g}{ }^{-1}$ ) may be of atmospheric origin. This estimate is based on a relatively conservative estimate of the lithogenic mass flux (values of up to $\sim 13 \mathrm{~g} \mathrm{~m}^{-2} \mathrm{y}^{-1}$ are reported). The remaining $40 \%$ of Ca-P in the surface sediments may be attributable to underestimation of the Ca-P input in dust, authigenic Ca-P formation in the water column or deposition of other stable $\mathrm{Ca}-\mathrm{P}$ species from the water column.
Atmospheric Ca-P, which is essentially transported authigenic Ca-P, forms part of the authigenic Ca-P (or detrital P) during sequential $\mathrm{P}$ extraction. As such, the experimentally determined $\mathrm{C}_{\text {org }} / \mathrm{P}_{\text {reactive }}$ ratio is lowered and no longer accurately reflects the burial efficiency of $\mathrm{P}$ delivered in OM. Figure 10 shows the $\mathrm{C}_{\text {org }} / \mathrm{P}_{\text {reactive }}$ ratio in surface sediments (top $2 \mathrm{~cm}$ ) before and after correcting for unreactive Ca-P, using the above-mentioned estimate of $\sim 8 \mu \mathrm{mol} \mathrm{g}^{-1}$. The increased $\mathrm{C}_{\text {org }} / \mathrm{P}_{\text {reactive }}$ ratios after correction show that across the depth transect, sedimentary retention of $\mathrm{P}$ delivered in reactive form is much less efficient than indicated by the uncorrected $\mathrm{C}_{\text {org }} / \mathrm{P}_{\text {reactive }}$ ratio. Despite significantly higher $\mathrm{BWO}$ concentrations (Table 1 ), the sedimentary $\mathrm{C}_{\text {org }} / \mathrm{P}_{\text {reactive }}$ ratios in the lower boundary of the OMZ are similar to those in the heart of the OMZ. This may be explained by the fact that higher $\mathrm{P}$ depositional fluxes and pore-water $\mathrm{HPO}_{4}^{2-}$ concentrations drive $P$ authigenesis and relatively efficient $P$ sequestration in the heart of the OMZ. The RTM results show that at station 4 in the lower boundary of the OMZ, only $14 \%$ of total $\mathrm{P}$ and $6 \%$ of reactive $\mathrm{P}$ that reaches the sedimentwater interface is buried below $27 \mathrm{~cm}$ sediment depth. This value for the reactive $\mathrm{P}$ burial efficiency is much lower than that calculated by Schenau and De Lange (2001). Using reactive $\mathrm{P}$ as determined by the same sequential $\mathrm{P}$ extraction scheme as in this study (Ruttenberg, 1992), they calculated a reactive $\mathrm{BE}$ of $55 \%$ for sediments at a site on the Pakistan margin with similar depth and BWO concentration (1254 mbss, $\left.12.5 \mu \mathrm{mol} \mathrm{O}_{2} \mathrm{~L}^{-1}\right)$ as station 4 (1306 mbss, $\left.\sim 14 \mu \mathrm{mol} \mathrm{O}_{2} \mathrm{~L}^{-1}\right)$. It must be noted that the burial efficiency of total and reactive $\mathrm{P}$ may be underestimated as a result of the model overestimation of organic P deposition (Fig. 7). Therefore, the model was also run using a higher $\mathrm{C} / \mathrm{P}$ ratio for highly reactive OM (477/1, as experimentally determined for the bulk sediment). The modelled organic $\mathrm{P}$ profile in this scenario did not exhibit a surface enrichment, resulting in a better match with the experimental data (not shown). For this scenario, the modelled total $\mathrm{BE}$ was $37 \%$ and the reactive $\mathrm{BE}$ was $15 \%$, further supporting the low burial efficiency of reactive $P$ in the Arabian Sea and the importance of unreactive $\mathrm{P}$ burial to the total sedimentary $\mathrm{P}$ budget.

\subsection{Iron and sulfur cycling in the northern Arabian Sea}

Sedimentary Fe and $\mathrm{P}$ dynamics are strongly linked, yet the burial of these two elements across the investigated depth transect showed marked differences. While sedimentary P abundance showed a clear decrease from the OMZ to the deep sea, the $\mathrm{Fe} / \mathrm{Al}$ ratio in the surface sediments along the depth transect showed little variability (Fig. 3), indicating that there are only minor changes with depth in Fe deposition and sequestration at the sediment surface. Within cores, reductive $\mathrm{Fe}$ (oxyhydr)oxide dissolution at depth leads to the down-core decrease in $\mathrm{Fe}$ at all stations. The surface enrichment in $\mathrm{Fe}$ (oxyhydr)oxides is likely in part caused by precipitation of upward diffusing $\mathrm{Fe}^{2+}$. At station 10, the relatively 
high concentrations of total $\mathrm{Fe}$ and $\mathrm{Fe}_{\text {ox1 }}$ suggest that downslope sediment transport may have affected the Fe chemistry at the base of the Murray Ridge. Due to its location, this station may have also received some sediment from the adjacent Indus Fan.

The sedimentary Fe cycle and its impact on the $\mathrm{S}$ cycle in the Arabian Sea have been subject to research and debate for decades. The Arabian Sea is unusual in that pyrite formation in the upper tens of centimeters of the sediment is limited, even in the OMZ which is characterized by low BWO concentrations and large depositional fluxes of OM. The very low pyrite concentrations in the sediments at stations 1B and 4 confirm the general lack of pyrite formation in the Arabian Sea OMZ. In contrast, pyrite is a significant sink for $\mathrm{Fe}$ at depth in the core from station 2, accounting for up to $40 \%$ of highly reactive Fe (Fig. 6). Such pyrite concentrations are unusual for surface sediments from the Arabian Sea and, together with the strong P enrichment between $\sim 15$ and $26 \mathrm{~cm}$ core depth at station 2 and the abundance of subsurface $\mathrm{Fe}$ (oxyhydr)oxides at station 1B, emphasize the spatial and potentially even temporal variability in benthic conditions and sediment geochemistry associated with the OMZ.

The generally low pyrite abundance in Arabian Sea sediments has been attributed to low SRRs caused by the diagenetic formation of recalcitrant organic matter through sulfurization (Passier et al., 1997) or the limited availability of reactive Fe (Schenau et al., 2002). In contrast, Law et al. (2009) hypothesize that the abundance of reactive $\mathrm{Fe}$ (oxyhydr)oxides in Arabian Sea surface sediments may suppress sulfate reduction and pyrite formation. These suggestions have been qualitative in nature, based on interpretation of sedimentary records. The application of the RTM to the dataset from station 4 provides a valuable opportunity to study sedimentary $\mathrm{Fe}$ and $\mathrm{S}$ dynamics on a quantitative basis. In general, the model seems to represent the role of sulfate reduction well. Earlier work has shown that there is a large variability in SRRs in the Arabian Sea (Boetius et al., 2000; Law et al., 2009). Nonetheless, the RTM gives a depth-integrated rate of $1.2 \mu \mathrm{mol} \mathrm{cm}{ }^{-2} \mathrm{yr}^{-1}$, which is similar to the depth-integrated value $(30 \mathrm{~cm}$ sediment depth) of $\sim 1.3 \mu \mathrm{mol} \mathrm{cm}-2 \mathrm{yr}^{-1}$ measured in a ${ }^{35} \mathrm{~S}$ tracer study by Boetius et al. (2000) using sediments from the deep western Arabian Sea. With a contribution of $\sim 10 \%$ to total OM oxidation, our RTM for station 4 results also confirm that sulfate reduction is a minor OM degradation pathway in the top 30$40 \mathrm{~cm}$ of Arabian Sea sediments (Lückge et al., 2002; Law et al., 2009).

Despite its modest role in OM degradation, sulfate reduction leads to appreciable pore-water $\mathrm{H}_{2} \mathrm{~S}$ concentrations in the RTM results for station 4. In our current model the rate of reaction between $\mathrm{Fe}^{2+}$ and $\mathrm{H}_{2} \mathrm{~S}$ is set to such a low value that, unrealistically, $\mathrm{Fe}^{2+}$ and $\mathrm{H}_{2} \mathrm{~S}$ coexist in the porewater (at concentrations of up to 15 and $60 \mu \mathrm{mol} \mathrm{L}^{-1}$, respectively). Prescribing literature-derived rate constants for the reaction between $\mathrm{Fe}^{2+}$ and $\mathrm{H}_{2} \mathrm{~S}$ in the model would re- sult in the depletion of pore-water $\mathrm{Fe}^{2+}$ by $\mathrm{FeS}_{(2)}$ formation with $\mathrm{H}_{2} \mathrm{~S}$ concentrations up to $\sim 60 \mu \mathrm{mol} \mathrm{L}{ }^{-1}$. This contrasts with the experimental data that showed up to $30 \mu \mathrm{mol} \mathrm{L} \mathrm{L}^{-1}$ $\mathrm{Fe}^{2+}$ and negligible $\mathrm{H}_{2} \mathrm{~S}$ (not shown). Also, solid-phase $\mathrm{FeS}_{2}$ would reach concentrations (up to $\sim 25 \mu \mathrm{mol} \mathrm{g}^{-1}$ ) exceeding those determined in the sequential extraction procedure $\left(\sim 2 \mu \mathrm{mol} \mathrm{g}^{-1}\right)$. This has direct consequences for the discussion on Fe and $\mathrm{S}$ cycling in the Arabian Sea. Our results suggest that pyrite formation is not suppressed by a limited supply of either pore-water $\mathrm{H}_{2} \mathrm{~S}$ or $\mathrm{Fe}^{2+}$, but rather by a rapid removal process for pore-water $\mathrm{H}_{2} \mathrm{~S}$ not accounted for in the model. It may be crucial to obtain a better understanding of the impact of the microbial community and dissolved organic compounds on the sedimentary S cycle. The suppression of pyrite formation limits Fe sequestration at depth in the sediment, leading to stronger upward diffusion of $\mathrm{Fe}^{2+}$ and surface enrichment in $\mathrm{Fe}$ (oxy)hydroxides, which in turn impacts the $\mathrm{P}$ retention capacity of the sediment.

\section{Conclusions}

In the Murray Ridge area of the northern Arabian Sea, authigenic $\mathrm{Ca}-\mathrm{P}$ formation is largely restricted to the oxygen minimum zone (OMZ) where relatively large fluxes of reactive $\mathrm{P}$, mainly in organic matter, are deposited at the sediment surface. Two investigated stations in the OMZ (Stations 1B and 2) showed large variability in $\mathrm{Fe}$ and $\mathrm{P}$ geochemistry, pointing towards both spatial and temporal changes in depositional conditions at these water depths. At deeper stations below the $\mathrm{OMZ}$ that receive less reactive $\mathrm{P}$ phases, porewater $\mathrm{HPO}_{4}^{2-}$ concentrations remain relatively low and authigenic Ca-P formation is limited or absent. Despite the more efficient sequestration of $\mathrm{P}$ as apatite in the OMZ, trends in sedimentary organic $\mathrm{C}$ to reactive $\mathrm{P}$ ratios indicate that low bottom water oxygen in general leads to a more efficient recycling of $\mathrm{P}$ from the sediment relative to organic $\mathrm{C}$.

Our results indicate that a significant fraction of the $\mathrm{P}$ that was operationally defined as authigenic Ca-P may in fact be unreactive $\mathrm{Ca}-\mathrm{P}$ that has been deposited from the water column. This Ca-P is likely derived from aeolian transport and possibly authigenic Ca-P formation in the water column. Application of the reactive transport model, which allowed for a detailed investigation of reactive $P$ sequestration, showed that at a station in the lower boundary of the $\mathrm{OMZ}$ as little as $\sim 10 \%$ of the reactive $\mathrm{P}$ depositional flux is retained below $27 \mathrm{~cm}$ depth in the sediment. This is much lower than previous estimates for the reactive $\mathrm{P}$ burial efficiency under similar conditions in the Arabian Sea. The contribution of unreactive $\mathrm{P}$ to the operationally-defined authigenic Ca-P pool also affects the organic $\mathrm{C}$ to reactive $\mathrm{P}\left(\mathrm{C}_{\mathrm{org}} / \mathrm{P}_{\text {reactive }}\right)$ ratios in the sediments along the depth transect. The $\mathrm{C}_{\text {org }} / \mathrm{P}_{\text {reactive }}$ ratio reflects the overall sedimentary reactive $\mathrm{P}$ burial efficiency and after correction for unreactive Ca-P, trends in $\mathrm{C}_{\text {org }} / \mathrm{P}_{\text {reactive }}$ 
reveal that the lowest P burial efficiency is observed around the lower boundary of the OMZ.

Reactive transport modelling of diagenesis at a station in the lower boundary of the OMZ shows that Fe redox cycling is crucial for $\mathrm{P}$ retention and authigenic Ca-P formation at this location. So far, Fe redox cycling has largely been neglected as a factor in P sequestration in the Arabian Sea. As is common in the Arabian Sea, the sediments at station 4 contain very little pyrite, whereas the model results suggest there is sufficient production of pore-water $\mathrm{Fe}^{2+}$ and $\mathrm{H}_{2} \mathrm{~S}$ to enable pyrite formation. Therefore, pyrite formation at this location seems to be curtailed by a factor other than limited availability of reactive $\mathrm{Fe}$ (oxyhydr)oxides or low sulfate reduction rates.

Acknowledgements. The Netherlands Organisation for Scientific Research is acknowledged for financial support to P. Kraal, D. C. Reed and C. P. Slomp (NWO Vidi grant). The 2009 PASOM research expedition was funded to G. J. Reichart by the Earth and Life Sciences (ALW) division of the Netherlands Organisation for Scientific Research (NWO) under number 817.01.015. C. P. Slomp acknowledges support from the European Research Council under the European Community's Seventh Framework Programme for ERC Starting Grant 278364. The shipboard party on the R/V Pelagia is acknowledged for their logistic and analytical support during the 2009 PASOM expedition. We are grateful to Klaas Nierop, Anne Steenbergh, Martin Ziegler and Karoliina Koho for assisting with on-board sediment and pore-water sampling and $\mathrm{O}_{2}$ micro-electrode measurements. We thank the staff of the Utrecht University integrated lab for the ICP-MS measurements and J. van Ooyen of Royal NIOZ for pore-water N and P analyses. Wim Boer of Royal NIOZ is acknowledged for performing the ${ }^{210} \mathrm{~Pb}$ analyses. Our PASOM project partners are thanked for their help with picking the foraminifera for ${ }^{14} \mathrm{C}$ dating. We thank Gabriel Filippelli, Aurelien Paulmier and two anonymous reviewers for their valuable comments that improved the quality of this paper.

Edited by: A. Paulmier

\section{References}

Algeo, T. J. and Ingall, E.: Sedimentary $\mathrm{C}_{\mathrm{org}}$ : $\mathrm{P}$ ratios, paleocean ventilation, and Phanerozoic atmospheric $p \mathrm{O}_{2}$, Palaeogeogr. Palaeocl., 256, 130-155, doi:10.1016/j.palaeo.2007.02.029, 2007.

Anderson, L. D., Delaney, M. L., and Faul, K. L.: Carbon to phosphorus ratios in sediments: implications for nutrient cycling, Global Biogeochem. Cy., 15, 65-79, doi:10.1029/2000gb001270, 2001.

Arrigo, K. R.: Marine microorganisms and global nutrient cycles, Nature, 437, 349-355, doi:10.1038/nature04159, 2005.

Badarinath, K. V. S., Kharol, S. K., Kaskaoutis, D. G., Sharma, A. R., Ramaswamy, V., and Kambezidis, H. D.: Longrange transport of dust aerosols over the Arabian Sea and Indian region - a case study using satellite data and ground- based measurements, Global Planet. Change, 72, 164-181, doi:10.1016/j.gloplacha.2010.02.003, 2010.

Bange, H. W., Naqvi, S. W. A., and Codispoti, L. A.: The nitrogen cycle in the Arabian Sea, Prog. Oceanogr., 65, 145-158, doi:10.1016/j.pocean.2005.03.002, 2005.

Banse, K.: Seasonality of phytoplankton chlorophyll in the Central and Northern Arabian sea, Deep Sea Res., 34, 713-723, doi:10.1016/0198-0149(87)90032-X, 1987.

Berg, P., Rysgaard, S., and Thamdrup, B.: Dynamic modeling of early diagenesis and nutrient cycling. A case study in an Arctic marine sediment, Am. J. Sci., 303, 905-955, doi:10.2475/ajs.303.10.905, 2003.

Boer, W., Van den Bergh, G. D., De Haas, H., De Stigter, H. C., Gieles, R., and Van Weering, T. C. E.: Validation of accumulation rates in Teluk Banten (Indonesia) from commonly applied Pb210 models, using the 1883 Krakatau tephra as time marker, Mar. Geol., 227, 263-277, doi:10.1016/j.margeo.2005.12.002, 2006.

Boetius, A., Ferdelman, T., and Lochte, K.: Bacterial activity in sediments of the deep Arabian Sea in relation to vertical flux, Deep-Sea Res. Pt. II, 47, 2835-2875, doi:10.1016/S09670645(00)00051-5, 2000.

Boudreau, B. P.: On the equivalence of nonlocal and radial-diffusion models for porewater irrigation J. Mar. Res., 42, 731-735, 1984.

Boudreau, B. P.: Mathematics of tracer mixing in sediments. II. Nonlocal mixing and biological conveyor-belt phenomena, Am. J. Sci., 286, 199-238, doi:10.2475/ajs.286.3.199, 1986.

Boudreau, B. P.: A method-of-lines code for carbon and nutrient diagenesis in aquatic sediments, Comput. Geosci., 22, 479-496, 1996.

Boudreau, B. P.: Diagenetic models and their implementation: modelling transport and reactions in aquatic sediments, SpringerVerlag, 1997.

Canfield, D. E., Raiswell, R., Westrich, J. T., Reaves, C. M., and Berner, R. A.: The use of chromium reduction in the analysis of reduced inorganic sulfur in sediments and shales, Chem. Geol., 54, 149-155, doi:10.1016/0009-2541(86)90078-1, 1986.

Compton, J., Mallinson, D., Glenn, C. R., Filippelli, G. M., Föllmi, K. B., Shields, G., and Zanin, Y.: Variations in the global phosphorus cycle, in: Marine authigenesis: from global to microbial, SEPM Spec. Pub., 21-33, 2000.

Cowie, G. L. and Levin, L. A.: Benthic biological and biogeochemical patterns and processes across an oxygen minimum zone (Pakistan margin, NE Arabian Sea), Deep-Sea Res. Pt. II, 56, 261270, doi:10.1016/j.dsr2.2008.10.001, 2009.

Eijsink, L. M., Krom, M. D., and Herut, B.: Speciation and burial flux of phosphorus in the surface sediments of the Eastern Mediterranean, Am. J. Sci., 300, 483-503, doi:10.2475/ajs.300.6.483, 2000.

Emerson, S., Jahnke, R., and Heggie, D.: Sediment-water exchange in shallow water estuarine sediments, J. Mar. Res., 42, 709-730, doi:10.1357/002224084788505942, 1984.

Faul, K. L., Paytan, A., and Delaney, M. L.: Phosphorus distribution in sinking oceanic particulate matter, Mar. Chem., 97, 307-333, doi:10.1016/j.marchem.2005.04.002, 2005.

Föllmi, K. B.: The phosphorus cycle, phosphogenesis and marine phosphate-rich deposits, Earth-Sci. Rev., 40, 55-124, doi:10.1016/0012-8252(95)00049-6, 1996.

Froelich, P. N., Arthur, M. A., Burnett, W. C., Deakin, M., Hensley, V., Jahnke, R., Kaul, L., Kim, K. H., Roe, K., Soutar, A., 
and Vathakanon, C.: Early diagenesis of organic-matter in Peru continental-margin sediments - phosphorite precipitation, Mar. Geol., 80, 309-343, doi:10.1016/0025-3227(88)90095-3, 1988.

Gächter, R., Meyer, J. S., and Mares, A.: Contribution of bacteria to release and fixation of phosphorus in lake-sediments, Limnol. Oceanogr., 33, 1542-1558, 1988.

Goldberg, E. D. and Koide, M.: Geochronological studies of deep sea sediments by the ionium/thorium method, Geochim. Cosmochim. Acta, 26, 417-450, doi:10.1016/0016-7037(62)901126, 1962.

Goldhammer, T., Bruchert, V., Ferdelman, T. G., and Zabel, M.: Microbial sequestration of phosphorus in anoxic upwelling sediments, Nature Geosci., 3, 557-561, doi:10.1038/ngeo913, 2010.

Grandel, S., Rickert, D., Schlüter, M., and Wallmann, K.: Porewater distribution and quantification of diffusive benthic fluxes of silicic acid, nitrate and phosphate in surface sediments of the deep Arabian Sea, Deep-Sea Res. Pt. II, 47, 2707-2734, doi:10.1016/S0967-0645(00)00046-1, 2000.

Greenhalgh, R. and Riley, J. P.: The determination of fluorides in natural waters, with particular reference to sea water, Anal. Chim. Acta, 25, 179-188, doi:10.1016/0003-2670(61)80199-2, 1961.

Guinasso, N. L. and Schink, D. R.: Quantitative estimates of biological mixing rates in abyssal sediments, J. Geophys. Res.-Ocean. Atm., 80, 3032-3043, doi:10.1029/JC080i021p03032, 1975.

Haake, B., Ittekkot, V., Ramaswamy, V., Nair, R. R., and Honjo, S.: Fluxes of amino-acids and hexosamines to the deep Arabian Sea, Mar. Chem., 40, 291-314, doi:10.1016/0304-4203(92)90028-9, 1992.

Haake, B., Ittekkot, V., Rixen, T., Ramaswamy, V., Nair, R. R., and Curry, W. B.: Seasonality and interannual variability of particle fluxes to the deep Arabian sea, Deep-Sea Res. Pt. I, 40, 13231344, doi:10.1016/0967-0637(93)90114-I, 1993.

Honjo, S., Dymond, J., Prell, W., and Ittekkot, V.: Monsooncontrolled export fluxes to the interior of the Arabian Sea, Deep-Sea Res. Pt. II, 46, 1859-1902, doi:10.1016/S09670645(99)00047-8, 1999.

Hupfer, M., Rube, B., and Schmieder, P.: Origin and diagenesis of polyphosphate in lake sediments: a ${ }^{31}$ P-NMR study, Limnol. Oceanogr., 49, 1-10, doi:10.4319/lo.2004.49.1.0001, 2004.

Ingall, E. and Jahnke, R.: Evidence for enhanced phosphorus regeneration from marine sediments overlain by oxygen depleted waters, Geochim. Cosmochim. Acta, 58, 2571-2575, doi:10.1016/0016-7037(94)90033-7, 1994.

Ingall, E. D., Bustin, R. M., and Van Cappellen, P.: Influence of water column anoxia on the burial and preservation of carbon and phosphorus in marine shales, Geochim. Cosmochim. Acta, 57, 303-316, doi:10.1016/0016-7037(93)90433-W, 1993.

Jaeschke, A., Ziegler, M., Hopmans, E. C., Reichart, G., Jan, Lourens, L. J., Schouten, S., and Sinninghe Damsté, J. S.: Molecular fossil evidence for anaerobic ammonium oxidation in the Arabian Sea over the last glacial cycle, Paleoceanography, 24, PA2202, doi:10.1029/2008pa001712, 2009.

Jilbert, T., Slomp, C. P., Gustafsson, B. G., and Boer, W.: Beyond the Fe-P-redox connection: preferential regeneration of phosphorus from organic matter as a key control on Baltic Sea nutrient cycles, Biogeosciences, 8, 1699-1720, doi:10.5194/bg-8-16992011, 2011.
Jørgensen, B. B.: A comparison of methods for the quantification of bacterial sulfate reduction in coastal marine sediments. 2. Calculations from mathematical models, Geomicrobiol. J., 1, 29-51, doi:10.1080/01490457809377722, 1978.

Kolla, V., Ray, P. K., and Kostecki, J. A.: Surficial sediments of the Arabian Sea, Mar. Geol., 41, 183-204, doi:10.1016/00253227(81)90080-3, 1981.

Kraal, P., Slomp, C. P., Forster, A., Kuypers, M. M. M., and Sluijs, A.: Pyrite oxidation during sample storage determines phosphorus fractionation in carbonate-poor anoxic sediments, Geochim. Cosmochim. Acta, 73, 3277-3290, doi:10.1016/j.gca.2009.02.026, 2009.

Kraal, P., Slomp, C. P., and de Lange, G. J.: Sedimentary organic carbon to phosphorus ratios as a redox proxy in Quaternary records from the Mediterranean, Chem. Geol., 277, 167-177, doi:10.1016/j.chemgeo.2010.08.003, 2010.

Law, G. T. W., Shimmield, T. M., Shimmield, G. B., Cowie, G. L., Breuer, E. R., and Martyn Harvey, S.: Manganese, iron, and sulphur cycling on the Pakistan margin, Deep-Sea Res. Pt. II, 56, 305-323, doi:10.1016/j.dsr2.2008.06.011, 2009.

Lee, C., Murray, D. W., Barber, R. T., Buesseler, K. O., Dymond, J., Hedges, J. I., Honjo, S., Manganini, S. J., Marra, J., Moser, C., Peterson, M. L., Prell, W. L., and Wakeham, S. G.: Particulate organic carbon fluxes: compilation of results from the 1995 US JGOFS Arabian Sea process study: By the Arabian Sea carbon flux group, Deep-Sea Res. Pt. II, 45, 2489-2501, doi:10.1016/S0967-0645(98)00079-4, 1998.

Lee, C. M., Jones, B. H., Brink, K. H., and Fischer, A. S.: The upper-ocean response to monsoonal forcing in the Arabian Sea: seasonal and spatial variability, Deep-Sea Res. Pt. II, 47, 11771226, doi:10.1016/S0967-0645(99)00141-1, 2000.

Lückge, A., Ercegovac, M., Strauss, H., and Littke, R.: Early diagenetic alteration of organic matter by sulfate reduction in Quaternary sediments from the northeastern Arabian Sea, Mar. Geol., 158, 1-13, doi:10.1016/S0025-3227(98)00191-1, 1999.

Lückge, A., Horsfield, B., Littke, R., and Scheeder, G.: Organic matter preservation and sulphate uptake into sediments from the continental margin off Pakistan, Org. Geochem., 33, 477-488, doi:10.1016/S0146-6380(01)00171-1, 2002.

Meile, C., Berg, P., Van Cappellen, P., and Tuncay, K.: Solute-specific pore water irrigation: Implications for chemical cycling in early diagenesis, J. Mar. Res., 63, 601-625, doi:10.1357/0022240054307885, 2005.

Moodley, L., Middelburg, J. J., Herman, P. M. J., Soetaert, K., and de Lange, G. J.: Oxygenation and organic-matter preservation in marine sediments: Direct experimental evidence from ancient organic carbon-rich deposits, Geology, 33, 889-892, doi:10.1130/g21731.1, 2005.

Nair, R. R., Ittekkot, V., Manganini, S. J., Ramaswamy, V., Haake, B., Degens, E. T., Desai, B. N., and Honjo, S.: Increased particle flux to the deep ocean related to monsoons, Nature, 338, 749751, doi:10.1038/338749a0, 1989.

Naqvi, S. W. A., Bange, H. W., Gibb, S. W., Goyet, C., Hatton, A. D., and Upstill-Goddard, R. C.: Biogeochemical oceanatmosphere transfers in the Arabian Sea, Prog. Oceanogr., 65, 116-144, doi:10.1016/j.pocean.2005.03.005, 2005.

Naqvi, S. W. A., Moffett, J. W., Gauns, M. U., Narvekar, P. V., Pratihary, A. K., Naik, H., Shenoy, D. M., Jayakumar, D. A., Goepfert, T. J., Patra, P. K., Al-Azri, A., and Ahmed, S. I.: The Arabian Sea 
as a high-nutrient, low-chlorophyll region during the late Southwest Monsoon, Biogeosciences, 7, 2091-2100, doi:10.5194/bg7-2091-2010, 2010.

Okin, G. S., Baker, A. R., Tegen, I., Mahowald, N. M., Dentener, F. J., Duce, R. A., Galloway, J. N., Hunter, K., Kanakidou, M., Kubilay, N., Prospero, J. M., Sarin, M., Surapipith, V., Uematsu, M., and Zhu, T.: Impacts of atmospheric nutrient deposition on marine productivity: Roles of nitrogen, phosphorus, and iron, Global Biogeochem. Cy., 25, GB2022, doi:10.1029/2010gb003858, 2011.

Olson, D. B., Hitchcock, G. L., Fine, R. A., and Warren, B. A.: Maintenance of the low-oxygen layer in the central Arabian Sea, Deep-Sea Res. Pt. II, 40, 673-685, doi:10.1016/09670645(93)90051-N, 1993.

Palastanga, V., Slomp, C. P., and Heinze, C.: Long-term controls on ocean phosphorus and oxygen in a global biogeochemical model, Global Biogeochem. Cycles, 25, GB3024, doi:10.1029/2010gb003827, 2011.

Paropkari, A. L., Prakash Babu, C., and Mascarenhas, A.: A critical evaluation of depositional parameters controlling the variability of organic carbon in Arabian Sea sediments, Mar. Geol., 107, 213-220, doi:10.1016/0025-3227(92)90168-H, 1992.

Passier, H. F., Luther III, G. W., and De Lange, G. J.: Early diagenesis and sulphur speciation in sediments of the Oman Margin, northwestern Arabian Sea, Deep-Sea Res. Pt. II, 44, 1361-1380, doi:10.1016/S0967-0645(97)00014-3, 1997.

Paytan, A., Cade-Menun, B. J., McLaughlin, K., and Faul, K. L.: Selective phosphorus regeneration of sinking marine particles: evidence from ${ }^{31} \mathrm{P}-\mathrm{NMR}$, Mar. Chem., 82, 55-70, doi:10.1016/S0304-4203(03)00052-5, 2003.

Poulton, S. W., and Canfield, D. E.: Development of a sequential extraction procedure for iron: implications for iron partitioning in continentally derived particulates, Chem. Geol., 214, 209-221, doi:10.1016/j.chemgeo.2004.09.003, 2005.

Prakash Babu, C., and Nath, B. N.: Processes controlling forms of phosphorus in surficial sediments from the eastern Arabian Sea impinged by varying bottom water oxygenation conditions, Deep-Sea Res. Pt. II, 52, 1965-1980, doi:10.1016/j.dsr2.2005.06.004, 2005.

Raiswell, R. and Canfield, D. E.: Sources of iron for pyrite formation in marine sediments, Am. J. Sci., 298, 219-245, doi:10.2475/ajs.298.3.219, 1998.

Ramaswamy, V. and Nair, R.: Fluxes of material in the Arabian Sea and Bay of Bengal - Sediment trap studies, J. Earth Syst. Sci., 103, 189-210, doi:10.1007/bf02839536, 1994.

Redfield, A. C.: The biological control of chemical factors in the environment, Am. Sci., 46, 205-222, 1958.

Reed, D. C., Slomp, C. P., and de Lange, G. J.: A quantitative reconstruction of organic matter and nutrient diagenesis in Mediterranean Sea sediments over the Holocene, Geochim. Cosmochim. Acta, 75, 5540-5558, doi:10.1016/j.gca.2011.07.002, 2011a.

Reed, D. C., Slomp, C. P., and Gustafsson, B. G.: Sedimentary phosphorus dynamics and the evolution of bottom water hypoxia: a coupled benthic-pelagic model of a coastal system, Limnol. Oceanogr., 56, 1075-1092, doi:10.4319/lo.2011.56.3.1075, 2011 b.

Reichart, G. J., Den Dulk, M., Visser, H. J., Van der Weijden, C. H., and Zachariasse, W. J.: A $225 \mathrm{kyr}$ record of dust supply, paleoproductivity and the oxygen minimum zone from the Murray ridge (northern Arabian sea), Palaeogeogr. Palaeocl., 134, 149169, doi:10.1016/S0031-0182(97)00071-0, 1997.

Rickard, D., and Luther, G. W.: Kinetics of pyrite formation by the $\mathrm{H} 2 \mathrm{~S}$ oxidation of iron(II) monosulfide in aqueous solutions between 25 and 125 degrees C: The mechanism, Geochim. Cosmochim. Acta, 61, 135-147, doi:10.1016/S00167037(96)00321-3, 1997.

Ruttenberg, K. C.: Development of a sequential extraction method for different forms of phosphorus in marine sediments, Limnol. Oceanogr., 37, 1460-1482, 1992.

Ruttenberg, K. C. and Berner, R. A.: Authigenic apatite formation and burial in sediments from non-upwelling, continentalmargin environments, Geochim. Cosmochim. Acta, 57, 9911007, doi:10.1016/0016-7037(93)90035-U, 1993.

Schenau, S. J. and De Lange, G. J.: Phosphorus regeneration vs. burial in sediments of the Arabian Sea, Mar. Chem., 75, 201217, doi:10.1016/S0304-4203(01)00037-8, 2001.

Schenau, S. J., Slomp, C. P., and De Lange, G. J.: Phosphogenesis and active phosphorite formation in sediments from the Arabian Sea oxygen minimum zone, Mar. Geol., 169, 1-20, doi:10.1016/S0025-3227(00)00083-9, 2000.

Schenau, S. J., Passier, H. F., Reichart, G. J., and de Lange, G. J.: Sedimentary pyrite formation in the Arabian Sea, Mar. Geol., 185, 393-402, doi:10.1016/S0025-3227(02)00183-4, 2002.

Schenau, S. J., Reichart, G. J., and De Lange, G. J.: Phosphorus burial as a function of paleoproductivity, Geochim. Cosmochim. Acta, 69, 919-931, doi:10.1016/j.gca.2004.05.044, 2005.

Sea-Bird Electronics Inc.: SBE 43 dissolved oxygen sensor, Application Note No. 64, 2011.

Slomp, C. P., Epping, E. H. G., Helder, W., and Van Raaphorst, W.: A key role for iron-bound phosphorus in authigenic apatite formation in North Atlantic continental platform sediments, J. Mar. Res., 54, 1179-1205, doi:10.1357/0022240963213745, 1996a.

Slomp, C. P., Van der Gaast, S. J., and Van Raaphorst, W.: Phosphorus binding by poorly crystalline iron oxides in North Sea sediments, Mar. Chem., 52, 55-73, doi:10.1016/03044203(95)00078-X, 1996b.

Slomp, C. P., Thomson, J., and De Lange, G. J.: Enhanced regeneration of phosphorus during formation of the most recent eastern Mediterranean sapropel (S1), Geochim. Cosmochim. Acta, 66, 1171-1184, doi:10.1016/S0016-7037(01)00848-1, 2002.

Slomp, C. P. and Van Cappellen, P.: The global marine phosphorus cycle: sensitivity to oceanic circulation, Biogeosciences, 4, 155171, doi:10.5194/bg-4-155-2007, 2007.

Steenbergh, A. K., Bodelier, P. L. E., Hoogveld, H. L., Slomp, C. P., and Laanbroek, H. J.: Phosphatases relieve carbon limitation of microbial activity in Baltic Sea sediments along a redox-gradient, Limnol. Oceanogr., 56, 2018-2026, doi:10.4319/lo.2011.56.6.2018, 2011.

Strickland, J. D. and Parsons, T. R.: A practical handbook of seawater analysis, Bull. Fish. Red. Bd. Can., 167, 1972.

Stuiver, M. and Reimer, P. J.: Extended C-14 data-base and revised Calib 3.0 C-14 age calibration program, Radiocarbon, 35, 215230, 1993.

Suess, E.: Phosphate regeneration from sediments of the Peru continental margin by dissolution of fish debris, Geochim. Cosmochim. Acta, 45, 577-588, doi:10.1016/0016-7037(81)901915,1981 . 
Suthhof, A., Jennerjahn, T. C., Schäfer, P., and Ittekkot, V.: Nature of organic matter in surface sediments from the Pakistan continental margin and the deep Arabian Sea: amino acids, Deep-Sea Res. Pt. II, 47, 329-351, doi:10.1016/S0967-0645(99)00109-5, 2000.

Swallow, J. C.: Some aspects of the physical oceanography of the Indian Ocean, Deep-Sea Res., 31, 639-650, doi:10.1016/01980149(84)90032-3, 1984.

Tsandev, I., Reed, D. C., and Slomp, C. P.: Phosphorus diagenesis in deep-sea sediments: sensitivity to water column conditions and global scale implications, in review, Chem. Geol., 2010.

Turekian, K. K. and Wedepohl, K. H.: Distribution of the elements in some major units of the Earth's crust, Geol. Soc. Am. Bull., 72, 175-192, doi:10.1130/0016-7606(1961)72[175:doteis]2.0.co;2, 1961.

Tyrrell, T.: The relative influences of nitrogen and phosphorus on oceanic primary production, Nature, 400, 525-531, doi:10.1038/22941, 1999.

Van Cappellen, P. and Berner, R. A.: A mathematical model for the early diagenesis of phosphorus and fluorine in marine sediments; apatite precipitation, Am. J. Sci., 288, 289-333, 1988.

Van der Weijden, C. H., Reichart, G. J., and Visser, H. J.: Enhanced preservation of organic matter in sediments deposited within the oxygen minimum zone in the northeastern Arabian Sea, DeepSea Res. Pt. I, 46, 807-830, doi:10.1016/S0967-0637(98)000934, 1999.
Van Santvoort, P. J. M., De Lange, G. J., Thomson, J., Colley, S., Meysman, F. J. R. and Slomp, C. P.: Oxidation and origin of organic matter in surficial Eastern Mediterranean hemipelagic sediments, Aquat. Geochem., 8, 153-175, doi:10.1023/A:1024271706896, 2002.

Wang, Y. and Van Cappellen, P.: A multicomponent reactive transport model of early diagenesis: Application to redox cycling in coastal marine sediments, Geochim. Cosmochim. Acta, 60, 2993-3014, doi:10.1016/0016-7037(96)00140-8, 1996.

Westrich, J. T. and Berner, R. A.: The role of sedimentary organicmatter in bacterial sulfate reduction - The G model tested, Limnol. Oceanogr., 29, 236-249, doi:10.4319/1o.1984.29.2.0236, 1984.

Woulds, C. and Cowie, G. L.: Sedimentary pigments on the Pakistan margin: Controlling factors and organic matter dynamics, DeepSea Res. Pt. II, 56, 347-357, doi:10.1016/j.dsr2.2008.05.033, 2009.

Wyrtki, K.: Physical oceanography of the Indian Ocean, in: The biology of the Indian Ocean, edited by: Zeitschel, B., Ecological Studies, Springer Verlag, 18-36, 1973. 